\title{
Empirical estimation of the option premium for residential redevelopment
}

John M. Clapp

Katsiaryna Salavei Bardos

Fairfield University, kbardos@fairfield.edu

S. K. Wong

Follow this and additional works at: https://digitalcommons.fairfield.edu/business-facultypubs

Copyright 2012 Elsevier, Regional Science and Urban Economics

NOTICE: this is the author's version of a work that was accepted for publication in Regional

Science and Urban Economics. Changes resulting from the publishing process, such as peer

review, editing, corrections, structural formatting, and other quality control mechanisms may not be reflected in this document. Changes may have been made to this work since it was submitted for publication. A definitive version was subsequently published in Regional Science and Urban Economics, [42, 1-2, 2012] DOI: 10.1016/j.regsciurbeco.2011.08.007

\section{Peer Reviewed}

\section{Repository Citation}

Clapp, John M.; Salavei Bardos, Katsiaryna; and Wong, S. K., "Empirical estimation of the option premium for residential redevelopment" (2012). Business Faculty Publications. 28.

https://digitalcommons.fairfield.edu/business-facultypubs/28

\section{Published Citation}

Clapp, John M., Katsiaryna Salavei Bardos, and S.K. Wong. 2012. Empirical estimation of the option premium for residential redevelopment. Regional Science and Urban Economics 42 (1-2) 240-256.

This item has been accepted for inclusion in DigitalCommons@Fairfield by an authorized administrator of DigitalCommons@Fairfield. It is brought to you by DigitalCommons@Fairfield with permission from the rightsholder(s) and is protected by copyright and/or related rights. You are free to use this item in any way that is permitted by the copyright and related rights legislation that applies to your use. For other uses, you need to obtain permission from the rights-holder(s) directly, unless additional rights are indicated by a Creative Commons license in the record and/or on the work itself. For more information, please contact digitalcommons@fairfield.edu. 


\title{
Empirical estimation of the option premium for residential redevelopment
}

This version: July 27, 2011

Deleted: March 7

Deleted: 5

\begin{abstract}
:
This paper presents and validates a novel empirical approach for measuring the value of option to redevelop using a standard hedonic dataset. Our analysis generalizes the standard hedonic model to account for the option value of reconfiguring hedonic characteristics. We test this model with over 162,000 real estate transactions in 53 towns in Connecticut between 1994 and 2007 by adding a non-linear intensity variable, which increases with the aggregate value of structure and decreases with land value. A conservative estimate is that about $20 \%$ of towns have positive option to redevelop, with a mean value of $29-34 \%$ for properties most like vacant land. Multiple tests across towns support predictions of real options theory. Positive option value towns have higher house price volatility and estimated option value varies positively with price volatility, a finding inconsistent with NPV theory. We also find positive association between option value and drift in house prices and a U-shape relation with house price adjusted for structural characteristics. Higher property taxes reduce the value of option to redevelop.
\end{abstract}




\section{Introduction}

Real options theory has made important contributions to the valuation literature. One of its key insights is that investment in irreversible assets should take place only when a trigger value is above investment costs because of the presence of the nonnegative option to wait (McDonald and Siegel, 1986; Dixit, 1989, Majd and Pindyck, 1987). Using simulations, Dixit and Pindyck (1994) show that the optimal hurdle price that triggers irreversible investment can be 3 times as large as when the investment is reversible. Related literature has shown that the timing of corporate investment decisions depends on the value of the option to wait (Able, 1983, Dixit and Pyndick, 1994).

Real estate is the most widely studied application of real options (Wang and Zhou, 2006); the value of the underlying asset is the property value with a new, optimal building and the strike price is the cost of construction. Titman (1985) and Williams (1991, 1993) developed the first applications of real options theory for pricing of land, focusing on the optimal timing and scale of vacant land development and redevelopment. Capozza and Li (1994) and Capozza and Sick (1994) combine options theory with monocentric urban economic theory and analyze the effect of changes in model parameters on development of vacant land at the urban fringe. Grenadier (1996) develops a game-theoretic approach to explaining overbuilding in real estate markets. Rosenthal and Helsley (1994) focus on the decision to demolish and redevelop housing. Brueckner and Rosenthal (2006) and Rosenthal (2008) point out that depreciated structures on high valued land are likely to be redeveloped. Dye and McMillen (2007) use hedonic regressions and demolition permits to estimate value at the point of redevelopment. 
Several papers studying the correlation between different measures of uncertainty and aggregate real estate development generally find support for real options theory. For example, Sivitanidou and Sivitanides (2000) find that greater demand volatility is associated with lower office-commercial construction rates. Mayer and Somerville (2000) find that developers wait longer to develop single family properties when the volatility of returns is high. Downing and Wallace (2001) study the decision to improve residential real estate by homeowners and find that the volatility of the spread between the return on housing and the cost of capital depresses investment. Wu and Cho (2007) find that land development is more likely to take place in areas with high uncertainty about net returns to farmland and low uncertainty about net returns to developed land.

Cunningham (2006) finds negative association between real estate development and price uncertainty, and positive association between land prices and uncertainty. He shows that a one-standard-deviation increase in uncertainty decreases the probability of development by 11 percent and increases vacant land prices by 1.6 percent. Consistent with option theory, Cunningham (2007) further finds that after the imposition of an urban growth boundary in Seattle area, price uncertainty no longer delays investment.

The problem with this stream of literature is that there are competing explanations for the observed relationships suggested by real options theory. For example, a negative relationship between uncertainty and investment can also be attributed to nondiversifiable risk or incomplete markets in the presence of risk aversion. Increase in nondiversifiable risk reduces net present value of investment. Therefore, net present value (NPV) theory predicts the same negative relationship between risk and investment as option theory. Grenadier (2002) points out that competition can eliminate most or all of 
the value of delay, so the NPV rule may be empirically relevant. ${ }^{1}$ To address this issue, Bulan, Mayer and Somerville (2009) decompose total uncertainty into systematic and idiosyncratic risk. They find negative association of both measures with the probability of investment, providing support for real options theory rather than alternative interpretations. Similarly, Holland, Ott, and Riddough (2000) find negative short-term relationship between systematic and total risk and aggregate rate of construction for commercial real estate.

Rather than focusing on the relation between the likelihood or the level of development and volatility, our approach is to devise a new empirical method for measuring option value, then check for the predicted relationship between option value and volatility as well as other predictors of option value. ${ }^{2}$ In net present value theory, an increase in expected volatility decreases investment value, whereas option value theory predicts an opposite relation because the portion of the asset value that can be attributed to option value is increasing in volatility. ${ }^{3} \mathrm{We}$ ask whether one can construct an empirical method to identify high option value for individual properties; our method can be applied to large databases without using neighborhood information. ${ }^{4}$

\footnotetext{
${ }^{1}$ Grenadier (1999) argues that information cascades can cause firms to ignore private information, possibly developing property earlier than without strategic exercise.

${ }^{2}$ Bulan, Mayer and Somerville (2009) and Grenadier (2002) point out that competition may drive markets to develop early, pushing the optimal time towards the net present value rule and eliminating the value of the option to wait. Our model predicts a positive association between volatility and options value, whereas NPV theory predicts that value declines with volatility.

${ }^{3}$ Please see Clapp et al. (2011) for formal derivation of asset value as a summation of hedonic use value and option value.

${ }^{4}$ By way of contrast, Clapp and Salavei (2010) use a small geocoded dataset; their model requires detailed identification of desirable neighborhoods.
} 
Real option value has long been modeled as a non-negative addition to the value of an existing real asset without the option. ${ }^{5}$ This implies the possibility of empirically estimating the value added by the option to develop or redevelop - NPV theory predicts that this part of value will be near zero. To the best of our knowledge, only one empirical paper, Quigg (1993), estimates the value of a real option as an addition to use value. ${ }^{6}$ Quigg defines an option premium as the percentage difference between the price when the option is in the money and intrinsic price, which is defined as the price when the option has near zero value. She finds that residential urban land prices contain a $1 \%$ to $11 \%$ option premium, with a mean of 5-6\% in Seattle during the 1976-79 period.

Quigg's (1993) theoretical model assumes that the price of the underlying asset (i.e., an optimal building) is observable. Her empirical analysis finds optimal building value for vacant land using hedonic model estimates for a sample of developed properties. However, she ignores the presence of option value in these developed properties. To remedy this and generalize from vacant land, we focus on the option to redevelop an existing structure. ${ }^{7}$ We use a general hedonic model that includes a nonnegative additive option value term.

The present paper contributes to the literature by developing methods to identify municipalities, counties or metropolitan areas likely to have significant redevelopment option value. We show that standard data readily available to practitioners using large

\footnotetext{
${ }^{5}$ Dixit (1989) and Capozza and Li (1994) model option value as additive to the present value of operating income from an existing asset.

${ }^{6}$ Quigg (1993) uses an infinite horizon continuous time options theoretic framework. She defines intrinsic asset value as the value when the variance of the underlying stochastic price process approaches zero. She assumes that before redevelopment the property yields net rents equal to a percentage of the value of the underlying (redeveloped) asset. Williams (1997) allows the pre-redevelopment value to depend on current realizations from the stochastic process and he allows repeated redevelopment.

${ }^{7}$ Transactions on vacant land are less widely available. Moreover, the urban land market is generally susceptible to entry barriers that compromise its contestability (Ching and Fu (2003)).
} 
databases, such as standard hedonic pricing data and a few basic municipal characteristics can successfully identify towns and properties with high and low option value. We further estimate the amount of option value present in each town and test if our estimates are correlated with house price volatility and other town characteristics according to options theory. This test requires variations in volatility, effective property tax rates, etc. across towns.

The town-level analysis provides a well-grounded approach to examination of option value associated with individual properties. Individual properties become attractive for redevelopment if the town's mix of public services and taxes increases property value, and if the town encourages renovation of the existing stock. On the other hand, little redevelopment option value would be available on the urban fringe and in a $\underline{\text { town encouraging development of vacant land. }}$

We start with the assumption that most towns have little redevelopment option value for a typical house within the town: i.e., any option value is isolated to a few neighborhoods. The reasons for this include: owner occupiers have high psychic costs associated with option exercise ${ }^{8}$ exercise increases supply and reduces option value for remaining properties; available vacant land (low household density) reduces redevelopment option value $;^{9}$ low price or low volatility of price reduce option value; price is greater than a trigger value in only a few sub periods; and, high effective property tax rates discourage redevelopment.

\footnotetext{
${ }^{8}$ For example, an elderly couple in a small, old house in a neighborhood with large new houses (i.e., when the option is clearly deep in the money) may not want to exercise.

${ }^{9}$ The use value of the existing structure must be sacrificed when it is exchanged for a new structure; this is not the case for vacant land.
}

Deleted: would

Deleted: rigorous evaluation of the contention that our method allows identification of individual properties

likely to have high option value along with a conservative estimate of the value of option to redevelop.

Deleted: analysis 
Starting with the knowledge that option value is limited in most towns, ${ }^{10}$ we motivate our study with the following question: can we measure the value of option to redevelop individual houses using a standard hedonic dataset, determine the amount of option value in the lower quartile of intensity (a measure of the existing value of structure divided by land value), and hence identify towns with significantly high option value?

Our measure of option value begins with hedonic theory (Rosen, 1974). The product of the existing hedonic vector and the vector of implicit market prices of each attribute represents the present value of the service flow from existing structure - the use value. ${ }^{11}$ The assumption underlying this standard hedonic model is that option value is near zero. Options pricing theory allows us to relax this assumption by adding option value to use value, i.e., property value is then the sum of use value and option value. The option value term is necessarily non negative and it is a function of the expected present value of the service flow from the redeveloped property less redevelopment cost and the foregone rent from the existing vector of hedonic characteristics.

We capture the presence of option value with an intensity variable, which is added to a standard vector of hedonic characteristics. ${ }^{12}$ Low intensity corresponds to high redevelopment potential - intensity increases with the value of the interior area, decreases in land value, and is lower in highly valued locations where the land value is high relative to the value of the structure. For each town, we estimate the marginal effect of intensity as the percentage price difference between low-intensity and high-intensity properties. A

\footnotetext{
${ }^{10}$ Option value can vary from property to property within a town. When we mention the option value of a | town, we always refer to the option value of a typical smaller, older house within the town.

${ }^{11}$ Of course, standard hedonic explanatory variables may "pick up" option value. But our goal is to separately measure the amount of option value, if any.

${ }_{12}$ Our method does not require teardowns whereas Rosenthal and Helsley (1994) and Dye and McMillen (2007) do. All we need is the possibility of substantial renovation - e.g., major rehabilitation of a historic building, where the exterior is protected from major change.
} 
town is said to have high option value for a typical house if low-intensity properties have significantly higher value than high-intensity properties, holding other hedonic characteristics constant. This method is motivated by the difference in value between a large new house (a "McMansion") and a neighboring small old house.

Our intensity measure is related to literature on land leverage (i.e. the ratio of land to property value). Bourassa et al. (2011), for example, showed that since land and structure values do not grow at the same rate, the degree of land leverage becomes important in explaining property price changes. Our study extends this idea by arguing that intensity (the reciprocal of land leverage minus one) captures redevelopment option value and is thus important in determining property price levels as well. To implement this idea, we use a nonlinear functional form implied by the theory of real options to identify option value as a percent of property value. This supplements the land leverage approach, which assumes that the value of improvements is separable from land value. ${ }^{13}$ Real options theory suggests that land value decreases as structure value increases because option value goes down. ${ }^{14}$

We estimate our model with over 162,000 real estate transactions in 53 towns in Connecticut (CT) between 1994 and 2007. This complements the analysis performed in Clapp and Salavei (2010) which focuses on a single town where they have detailed information on spatial characteristics such as distance from Long Island Sound. In this study we have a typical hedonic data set which lacks detailed location information; e.g., the Federal Housing Finance Authority (FHFA) has recently been tasked with developing

\footnotetext{
${ }^{13}$ Specifically, the land leverage literature assumes that the value of improvements is replacement cost less depreciation, with some exceptions such as historical value.

${ }^{14}$ I.e., everything else constant, larger newer houses are more likely to be close to optimum, so option value is lower than for smaller older houses.
} 
house price indices using all sales data aggregated at the region, metropolitan area and state level. ${ }^{15}$ This study differs in many ways from Clapp and Salavei (2010), whose main purpose was to provide empirical evidence that in the absence of correctly-specified variables for option value, hedonic estimates of implicit market prices will be biased. This paper focuses on estimating the value of option to redevelop for a large hedonic dataset containing standard property characteristics and on testing association between estimated option value and its determinants, such as volatility.

We further check for the predicted relationship between option value and other predictors of option value based on town level analysis; this level controls for property taxes, schools and other local public goods, as well as many location amenities. Town level analysis allows price indices estimated from the standard hedonic model to be used for estimating the volatility of price for each town. While the majority of towns in CT do not have much option value for a typical house, nearly $20 \%$ of towns are identified to have positive option value with a mean value of about $32 \% .{ }^{16}$ We show that volatility is an important variable separating those towns with high option value from others. Most important, both our cross-town and cross-period findings reject NPV theory in favor of option value theory: 1) towns with high volatility have high value of the option to redevelop and 2) option value increases with volatility in the 2001-2007 period but not the 1994-2000 period. Consistent with real options theory we also find that drift in house prices is positively associated with the value of option to redevelop; there is a U-shape

\footnotetext{
${ }^{15}$ The Housing and Economic Recovery Act (HERA, 2008) requires the FHFA to develop a method for tracking average U.S. house prices over time. Their researchers are assembling comprehensive databases, but they cannot control for location below the zip code level.

${ }^{16}$ This number applies only to the $25 \%$ of properties most like vacant land.
} 
relation between option value and house price adjusted for structural characteristics; effective property tax rates reduce the value of option to redevelop.

The paper makes several contributions to the literature. First, it develops a novel approach to measuring the value of option to redevelop for specific properties within and across towns. Like Quigg (1993), we put a number on the value of the option to redevelop. While both Quigg's (1993) and our measure of option value are subject to the estimation error, there are several advantages to our proxy for the option to redevelop. It can be easily calculated for large datasets. Furthermore, while motivated by theory, the measure is data driven and is not sensitive to the assumptions about model parameters as in Quigg (1993). Lastly, our method uses data on the sales of new and existing houses, which is much more widely available than sales of vacant land, zoning and demolition permits used in most previous studies of the option to redevelop.

Second, to the best of our knowledge, this is the first paper to evaluate the relation between estimated values of redevelopment options and volatility, which is the most direct test of the implications of the real options theory. ${ }^{17}$ Prior research studies the association between volatility and the propensity to develop. However, propensity to develop is not just a function of option to redevelop. Third, it is the first paper to test the relation between the value of the option to redevelop and socio-economic characteristics. Our result of negative association between taxes and redevelop value complements literature on development and regulation (e.g. Mayer and Somerville (2000)). Lastly, our separation of option value from use value and land value extends land leverage literature, which argues for the importance of decomposing property value into structure and land

\footnotetext{
${ }^{17}$ Quigg (1993) estimates volatility implied by her model, which assumes positive relationship between the value of the option to redevelop and volatility.
} 
value since these components can be influenced by different factors (see Bourassa at el (2011), Davis and Palumbo (2008) and Davis and Heathcote (2007), Bostic et al., (2007)).

The remainder of this paper is organized as follows: Section 2 discusses the implications of option to redevelop for the hedonic pricing model; Section 3 outlines empirical methods and hypotheses; Section 4 describes the data; Section 5 presents results; Section 6 compares our results to findings in related studies and Section 7 concludes.

\section{Option to redevelop and hedonic pricing model}

Hedonic theory deals with the pricing of commodities that can embody varying amounts of a vector of attributes $q$. Rosen (1974) develops a theoretical framework in which hedonic price function $P(q)$ is the equilibrium price arising from bids of buyers and sellers. A standard hedonic equation takes on the following form.

$$
P_{i}=\gamma+\alpha_{1} q_{1 i}+\alpha_{2} q_{2 i}+\ldots+\alpha_{n} q_{n i}+\varepsilon_{i}
$$

where $i$ indexes individual sales, each with $n$ hedonic characteristics, $\gamma$ is the intercept, and $\alpha_{i}$ measure implicit market prices. The iid disturbance term $\varepsilon$ arises from negotiation between buyers and sellers.

Clapp et al. (2011) derive a more general form of hedonic pricing model that incorporates the option to redevelop, and they show that cross-sectional hedonic equilibrium exists in the presence of additive option value. Rosen specifically excluded the value of durable assets from his theory to "avoid the complications of capital theory (1974, p. 37)." The hedonic model with real options is a solution to a standard hitting time problem, where the investor maximizes the expected net present value of an 
aggregate measure of the vector of hedonic characteristics, $q_{a}$. I.e., they consider the option to replace the vector of characteristics with a new aggregate level (the teardown option).

Empirical implications of theory can be motivated by the following standard solution for the price of a dividend paying asset in the presence of a call option: ${ }^{18}$

$$
P\left(q_{a}\right)=\frac{q_{a} p}{r-\mu}+B_{0} q_{a}^{B_{1}}, \text { where } B_{1}<0 \text { and } B_{0} \geq 0
$$

where $q_{a}$ is a scalar index of aggregate structure, $r$ is the discount rate and $\mu$ is the drift in price ( $p$ ) per unit of housing. ${ }^{19}$ The $B_{i}$ parameters are functions of: 1) the current level of price; 2) the parameters of the stochastic process for $p ; 3$ ) the parameters of the cost function; and 4) the solution to the fundamental quadratic equation.

The first term in equation (2) is the standard hedonic model specification and represents present value of the service flow from the current attributes of the asset. The second term is the value of the option to redevelop to an optimal aggregate level, $q_{a}^{n}$. It equals the expected present value of the level of service flow after redevelopment less the cost of redevelopment and less the loss of rents from the existing level of the asset. The existing level of the aggregate vector $q_{a}$ enters the option value term because the strike price increases in $q_{a}$. In cross-sectional hedonic equilibrium, it is $q_{a}$ that differs across sales. An important implication of this model is that the option term is additive to the

\footnotetext{
${ }^{18}$ Sick (1990, equations IV.7 - IV.11) derives a similar valuation equation for a dividend paying asset. In his model, as in equation (2), he first term is the present value of an infinite stream of dividends and the second (options value) term declines with the present value of dividends, which are added to the cost of exercise.

${ }^{19}$ A similar solution with depreciation, $\delta$, is developed in Williams (1997), equation (14).
} 
standard hedonic specification summarized by the first term on the right hand side of equation (2).

Equation (2) has $q_{a}$ in both terms. How does an empiricist separately identify use value (the first term) and option value (the second term)? The key is that land and structure affect property value in two different ways. Option pricing theory suggests that redevelopment is more likely when land value is high but structure value is low - i.e., a smaller, older structure on a valuable land parcel. On the other hand, hedonic pricing theory suggests that net present use value increases with both the value of land (e.g. better location and larger lot) and structure (e.g. larger interior area and newer building).

As discussed in Clapp and Salavei (2010), the standard hedonic model with an option to redevelop can be identified by the inclusion of a non-linear function of intensity measured as the ratio of the assessed structure value to assessed land value. ${ }^{20}$ When the value of structure is high relative to land value (e.g. large properties on small lots; new properties in suburban developments), the proposed measure of intensity is high; the property is close to optimal intensity. In such cases, we expect redevelopment potential to be small. On the other hand, low structure to land value ratio corresponds to low intensity and high redevelopment potential. An example of this is the teardown of small, old houses on large highly valued lots and their replacement with larger structures. ${ }^{21}$

\footnotetext{
${ }^{20}$ Assessed land and structure value for property tax purposes is publicly available information in most parts of the US and in many European countries. Assessors use considerably more information than is observed to researches to determine land and building value (See Clapp and Giaccotto, 1992). Most importantly for our research is that assessors in Connecticut observe whether or not a lot is suited for development (see Clapp and Salavei (2010) for detailed discussion of assessment process in Greenwich, CT). Property tax appeal is one of the mechanisms insuring that assessor gets the property and land value right, minimizing concern that the assessor simply assigns land value as a percent of total value.

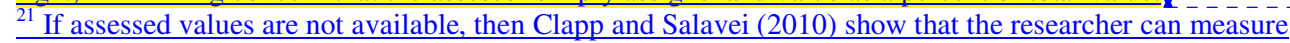
intensity by the ratio of interior size to average interior size of new houses within X-miles, where $\mathrm{X}$ depends on local geography.
}

Formatted: Highlight

Deleted: If assessed values are not available, then Clapp and Salavei (2010) show that the researcher can measure intensity by the ratio of interior size to average interior size of new houses within $\mathrm{X}$-miles, where $\mathrm{X}$ depends on local geography.

Formatted: Highlight 


\section{Empirical methods and hypotheses}

We use the model in equation (2) to measure the value of option to redevelop individual properties for each town. We estimate the hedonic model with a sample of 162,454 residential real estate transactions in 53 towns in the State of Connecticut between 1994 and 2007. We estimate the standard hedonic model and three specifications of the hedonic model augmented with intensity to capture the redevelopment potential. The latter specifications allow us to identify towns with high option value for a typical house. To verify whether the towns so identified really contain option value, we test if these towns are associated with the characteristics implied by real options theory; the key characteristic of interest is the volatility of house prices. First, we perform univariate analysis by comparing towns with positive option value to towns with zero option value. We then analyze the determinants of the likelihood of a town having positive option value using a logit model. Finally, we examine determinants of the value of the option to redevelop with tobit regressions.

We estimate the models separately for each town with sufficient data. This allows for Tiebout sorting effects: public services and taxes will be different for each town and these differences will be capitalized into property values. Town values can diverge over time, making options more or less valuable. In addition, each town has different zoning restrictions and different regulations governing demolition or major rehabilitation. ${ }^{22}$

\subsection{Standard and option-based hedonic models}

First, we estimate the following specification of the standard hedonic model.

\footnotetext{
${ }^{22}$ Permits for renovation, major rehabilitation and teardown of residential properties are not typically denied in Connecticut. However, regulations can make the process more or less onerous.
} 
Model 1: The standard cross-sectional hedonic model: ${ }^{23}$

$$
\ln \text { Price }=\alpha q+\varepsilon
$$

where Price is the sale price, $q$ is a vector of hedonic characteristics (including a vector of ones), and $\alpha$ is a vector of implicit market prices for each attribute. Our data provides for the following standard hedonic variables: age and age squared (Age and $\mathrm{Age}^{2}$ ), indicator variable that equals one if the property has two or three bedrooms (Bed2or3), indicator variable that equals one if the property has more than three bedrooms $(\operatorname{Bed} 3 p)$, interior square footage and footage squared $\left(F t g\right.$ and $F t g^{2}$ ), size of the lot in square feet and size squared (Lotsf and Lotsf $f^{2}$ ), and year dummies. ${ }^{24}$ Property location is controlled for through a set of land value indicator variables $\left(L V_{q}\right)$ interacted with footage and footage squared. $L V_{q}$ equals one when the residuals from regressing the log of assessed land value on the $\log$ of lot size is in its $q^{\text {th }}$ quartile. Equation (4) takes the following form: $:^{25}$

$$
\begin{aligned}
\ln \text { Price }= & \alpha_{0}+\sum_{q=2}^{4} \operatorname{LV}_{\mathrm{q}}\left(\alpha_{1 \mathrm{q}}+\alpha_{2 \mathrm{q}} \mathrm{Ftg}+\alpha_{3 \mathrm{q}} \mathrm{Ftg}^{2}\right)+\alpha_{4} \mathrm{Ftg}+\alpha_{5} \mathrm{Ftg}^{2}+\alpha_{6} \text { Lotsf }+ \\
& \alpha_{7} \text { Lotsf }^{2}+\alpha_{8} \text { Age }+\alpha_{9} \text { Age }^{2}+\alpha_{10} \text { Bath } 3 \mathrm{p}+\alpha_{11} \text { Bath2or } 3+\alpha_{t} \text { Year }_{t}+\varepsilon
\end{aligned}
$$

where Year $_{t}=1$ if the sale occurs in year $t$, otherwise zero.

As discussed earlier, a non-linear function of intensity can capture the redevelopment potential if added to the standard hedonic model. Intensity is defined as the ratio of assessed structure value to assessed land value. An advantage of this measure

\footnotetext{
${ }^{23}$ We omit property subscript $i$ in all equations for brevity.

${ }^{24}$ See Table 1 for more detailed variable description.

${ }^{25}$ Quartile indicator variables are used to approximate nonlinear functional forms throughout this paper. Their coefficients are easy to interpret Since these coefficients are estimated by ordinary least squares, they benefit from the robustness of that method.
} 
is that the value of land and structure are assessed infrequently, and the assessed values are determined by sales prices that occurred during earlier years. ${ }^{26}$ Therefore, our intensity variable is predetermined, reducing endogeneity concerns. ${ }^{27}$ For example, in West Haven, CT the assessor's office revalues properties every four years as required by state law. ${ }^{28}$ To deal with the problem of the revaluations that occur within our sample period, we de-trend the log of intensity (LINT) using the following auxiliary regression for each town:

$$
\operatorname{LINT}=\delta_{0}+\delta_{t} \text { Year }_{\mathrm{t}}+\omega
$$

The residual of regression $(5)\left(L I N T^{\prime}=\hat{\omega}\right)$ is then ranked and converted into two indicator variables: 1) LINT25' represents low intensity, which equals ten when the value of LINT' is in bottom $25 \%$ and zero otherwise, and 2) LINTG75' represents high intensity, which equals ten when the value of $L I N T^{\prime}$ is in top $25 \%$ and zero otherwise. These two indicator variables constitute the empirical counterpart to the intensity term, the last term in equation (2).

We estimate three different specifications of option-based hedonic model. The first model simply adds LINT25' and LINTG75' to equation (4). Since extremely lowintensity properties are like vacant land which could be readily developed, we also include a dummy variable $L I N T \_Z$ to capture the disproportional effect of very low intensity values, including the case where the value of structure is zero. LINT_Z equals ten when the value of LINT' is in bottom two percent, and zero otherwise.

\footnotetext{
${ }^{26}$ Major construction on any property triggers revaluation, but on the same basis as other valuations. For example, if a bedroom is added, it is valued as if it existed at the time of the last general revaluation.

${ }^{27}$ The concern is that our intensity measure is determined by some of the same omitted variables as the use value term. Note that we are using a nonlinear functional form to identify the part of property value that is option value. Both property value and option value are simultaneously determined in cross-sectional equilibrium by the parameters of equation (2). So the endogeneity issue reduces to an identification issue. ${ }^{28}$ Some towns obtain exceptions allowing longer time between revaluations.
} 
Model 2: Option-based hedonic model:

$$
\ln \text { Price }=\alpha q+\beta_{0} \text { LINT_Z }+\beta_{1} \text { LINT25' }+\beta_{2} \text { LINTG75' }+\varepsilon
$$

Here, $\alpha$ is a vector with dimension corresponding to $q$. The product $\alpha q$ summarizes all the terms in equation (4).

In Model 3 we isolate, more explicitly, the option value effect on age and depreciation by interacting Age and $A g e^{2}$ with LINT25' and LINTG75, ${ }^{29}$ Real options theory predicts that intensity should have a bigger effect for older properties. The strike price of the property that produces low revenue stream in its current form will be smaller. Therefore, a highly depreciated property will have a higher value of option to redevelop and a higher sensitivity to intensity changes than a newer property.

Model 3: Option-based hedonic model with LINT25' and LINTG75'-Age interaction

$$
\begin{aligned}
\ln \text { Price } & =\alpha q+\beta_{0} \text { LINT } \_+ \\
& \text {LINT25 }\left(\beta_{1}+\beta_{2} \text { Age }+\beta_{3} \text { Age }^{2}\right)+\operatorname{LINTG75}\left(\beta_{4}+\beta_{5} \text { Age }+\beta_{6} \text { Age }^{2}\right)+\varepsilon
\end{aligned}
$$

Our final model, Model 4, accounts for changing market conditions by including an indicator variable $B 00$ that equals one if the property is sold in or before 2000 and zero otherwise; and another indicator variable $A 00$ that equals one if the property is sold after 2000 and zero otherwise.

Model 4: Option-based hedonic model with LINT25' and LINTG75'-Age interaction and $B 00$ and $A 00$ indicators

$$
\begin{aligned}
& \ln \text { Price }=\chi q+\beta_{0} \text { LINT_Z }+ \\
& \operatorname{B00}\left[\operatorname{LINT} 25^{\prime}\left(\beta_{1}+\beta_{2} \text { Age }+\beta_{3} \text { Age }^{2}\right)+\operatorname{LINTG75}\left(\beta_{4}+\beta_{5} \text { Age }+\beta_{6} \text { Age }^{2}\right)\right]+ \\
& \mathrm{A} 00\left[\operatorname{LINT} 25^{\prime}\left(\beta_{7}+\beta_{8} \text { Age }+\beta_{9} \text { Age }^{2}\right)+\operatorname{LINTG75}\left(\beta_{10}+\beta_{11} \text { Age }+\beta_{12} \text { Age }^{2}\right)\right]+\varepsilon
\end{aligned}
$$

\footnotetext{
${ }^{29}$ It has been shown that age can capture characteristics other than depreciation. Age is correlated with omitted location and construction quality characteristics (Malpezzi et al. (1987)).
} 
Our data does not permit us to cross intensity with more sub-periods, but year 2000 seems to provide a natural time point to capture any significant shift in options value. The average interest rate of 1-year treasury bills was 5.5\% p.a. during 1994-2000, compared to $3.1 \%$ p.a. during 2001-07. The higher interest rates before 2000 should make call options more valuable. On the other hand, housing prices grew much faster during 2001-07, suggesting that higher rates of drift increased call option value after 2000. Also, we find that housing returns in Connecticut during 1994-2000 were less volatile than those during 2001-07 (5.5\% p.a. vs. $6.2 \%$ p.a.). ${ }^{30}$

We estimate Models 1-4 separately for each of 53 towns. Next we address interpretation of the LINT related coefficients: in particular, how are these coefficients used to identify the presence of option value for a typical property separately from the role of land value in the standard hedonic model?

Interpreting the land value coefficients

We model the effect of land value on capitalized rents with the $L V$ terms in equation (4). ${ }^{31}$ Correct specification of land value is important because the LINT variable is inversely related to land value and therefore could capture any omitted location characteristics other than option value within each town. We use a flexible functional form to separately identify the effect of land value and option value. In equation (4), land value enters as quartile dummies interacted with interior square footage. If these dummies are working to properly shift land value, then the effect of a given footage on

\footnotetext{
${ }^{30}$ Section 5.4 provides further analysis on the relationship between option values and volatilities during the whole time period and the two subperiods.

${ }^{31}$ See Clapp and Salavei (2010) for more on how land value is specified in the hedonic equation.
} 
value should increase as a function of the quartile dummy. From equation (4), the marginal effect of the land value dummy is:

$$
M E_{-} L V_{q}=\alpha_{1 q}+\alpha_{2 q} F \operatorname{tg} M+\alpha_{3 q} F \operatorname{tg} M^{2}
$$

where FtgM is the mean value of footage within the town.

If the assessor is correctly estimating land value, then $M E_{-} L V_{\mathrm{q}}$ must increase as the land value quartile increases:

Hypothesis 1: If land value increases capitalized rent for a given square footage in equation (4), then $M E_{-} L V_{\mathrm{q}}$ increases as follows:

$$
\begin{aligned}
& M E_{-} L V_{2}>0 \\
& M E_{-} L V_{3}>M E_{-} L V_{2} \\
& M E_{-} L V_{4}>M E_{-} L V_{3}
\end{aligned}
$$

The intuition is that higher land value should be reflected in higher per square foot prices and the estimated coefficients measure this effect. The hypothesis will not hold if the assessor is incorrectly estimating land value, or when the effect of land value is not fully captured by the functional form of equation (4).

Interpreting the LINT coefficients

We determine the presence of option value by calculating the marginal effect of properties in the lowest quartile of intensity for each town $k$ for each model, denoted as ME1 $1_{\mathrm{k}}$. ME1 $1_{\mathrm{k}}$ measures the $\ln ($ Price $)$ difference between a house with low (lower quartile) intensity and one with middle ( $25^{\text {th }}$ to $75^{\text {th }}$ quartile, the omitted category) intensity:

Model 2: $M E 1_{k}=10 \times\left(b_{1, k}+b_{0, k}\right)$

Model 3: $\operatorname{ME}_{\mathrm{k}}($ Age $)=10 \times\left[\mathrm{b}_{1, \mathrm{k}}+\mathrm{b}_{2, \mathrm{k}} \operatorname{Age}_{\mathrm{k}}+\mathrm{b}_{3, \mathrm{k}} \operatorname{Age}_{\mathrm{k}}^{2}+\mathrm{b}_{0, \mathrm{k}}\right]$ 
Model 4: $\operatorname{ME}_{\mathrm{k}}($ Age, subperiod $)=\mathrm{B} 00 \times 10 \times\left[\mathrm{b}_{1, \mathrm{k}}+\mathrm{b}_{2, \mathrm{k}} \mathrm{Age}_{\mathrm{k}}+\mathrm{b}_{3, \mathrm{k}} \mathrm{Age}_{\mathrm{k}}^{2}\right]+$

$$
\mathrm{A} 00 \times 10 \times\left[\mathrm{b}_{7, \mathrm{k}}+\mathrm{b}_{8, \mathrm{k}} \mathrm{Age}_{\mathrm{k}}+\mathrm{b}_{9, \mathrm{k}} \text { Age }_{\mathrm{k}}^{2}\right]+\mathrm{b}_{0, \mathrm{k}}
$$

where $b_{\mathrm{ik}}$ is the $i^{\text {th }}$ estimate of $\beta_{\mathrm{ik}}$ in Models 2 to 4 for the $k^{\text {th }}$ town and the marginal effect can be evaluated at any property Age. Note that equation (13a) implies different marginal effects for each time period identified by $B 00(\leq 2000)$ and $A 00(>2000)$.

Positive marginal effects $\left(\mathrm{ME} 1_{\mathrm{k}}>0\right)$ suggest positive option value, with the amount of option value equal to $M E 1_{k}$. Non-positive marginal effects $\left(M E 1_{k} \leq 0\right)$ indicate a town with zero option value. The marginal effects are for the lowest intensity (lowest quartile of LINT) properties: i.e., those with the highest possible redevelopment potential.

Next we consider a specification of option value that further controls for omitted location (land value) characteristics. This method uses the highest intensity properties, those in the LINTG75' category. It is motivated by two observations:

1. We would expect the best locations to be developed and redeveloped first, so the

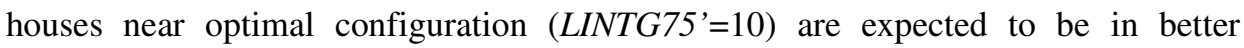
locations within a town. If location characteristics have been adequately controlled, LINTG75' houses should have little option value and its coefficient should be smaller than ME1 $1_{k}$.

2. Large new houses ("McMansions") are found within the same town as small older houses, often in the same block or neighborhood. In this case, we expect the coefficient on LINTG75' to be smaller than $M E 1_{\mathrm{k}}$. That is, the property with the smaller, older property is worth more than the larger, newer property because of 
option value. This can only be the case if we have correctly controlled for structural characteristics and land value with the explanatory variables in equation (4). ${ }^{32}$

Therefore, we further compare $\mathrm{ME} 1_{\mathrm{k}}$ with the coefficient on LINTG75' by calculating $M E 2_{\mathrm{k}}$, which is the $\ln$ (Price) difference between a house with low (lower quartile) intensity and one with high (upper quartile) intensity. If the following strong conditions also hold in towns with $M E 1_{\mathrm{k}}>0$, then land value has been controlled for and we have identified a town with high option value:

Model 2: $\mathrm{ME}_{\mathrm{k}}=\mathrm{ME}_{\mathrm{k}}-10 \times b_{2, k}=10 \times\left(b_{1, k}+b_{0, k}-b_{2, k}\right)>0$

Model 3: $\operatorname{ME}_{\mathrm{k}}($ Age $)=\operatorname{ME}_{\mathrm{k}}($ Age $)-10 \times\left[\mathrm{b}_{4, \mathrm{k}}+\mathrm{b}_{5, \mathrm{k}} \mathrm{Age}_{\mathrm{k}}+\mathrm{b}_{6, \mathrm{k}} \mathrm{Age}_{\mathrm{k}}^{2}\right]>0$

$M E 2_{\mathrm{k}}($ Age, subperiod $)=M E 1_{\mathrm{k}}($ Age, subperiod $)$

Model 4: $\quad-B 00 \times 10 \times\left(b_{4, k}+b_{5, k}\right.$ Agek $\left.+b_{6, k} A g e_{k}^{2}\right)$

$$
-A 00 \times 10 \times\left(b_{10, k}+b_{11, k} A g e k+b_{12, k} A g e_{k}^{2}\right)>0
$$

Hypothesis 2: Option value has been identified separately from land value if towns with $\mathrm{ME} 2_{\mathrm{k}}>0$ are also towns with $\mathrm{ME} 1_{\mathrm{k}}>0$. The two have not been correctly identified if towns have $\mathrm{ME} 2_{\mathrm{k}}>0$ but $\mathrm{ME} 1_{\mathrm{k}} \leq 0$ or if $\mathrm{ME} 1_{\mathrm{k}}>0$ and $\mathrm{ME} 2_{\mathrm{k}} \leq 0$.

The intuition is that the larger newer quartile of properties $\left(\operatorname{LINTG75}^{\prime}=10\right)$ will be

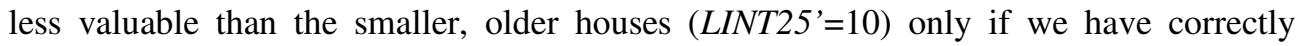
controlled for land value and structural characteristics. If $M E 1_{k}>0$ and $M E 2_{k}>0$, then we have identified positive option value towns. The rest of the towns are zero option value towns. Our identification of positive option value towns as those with both $\mathrm{ME} 1_{\mathrm{k}}>0$ and $\mathrm{ME} 2_{\mathrm{k}}>0$ also mitigates endogeneity concerns arising from the possibility that both these two quantities necessarily provide a conservative estimate because any misspecification of land value or structural characteristics will tend to produce rejection of $\mathrm{H} 2$. property prices and optimal level of development are affected by the same factors. Any bias in coefficients due to such endogeneity will have similar effect for houses with low

\footnotetext{
${ }^{32}$ If $\mathrm{H} 1$ is not confirmed (i.e., land value is not completely controlled in equation (4)), then $M E 1_{\mathrm{k}}>0$ and $\mathrm{ME} 2_{\mathrm{k}}>0$ will provide conservative (downwardly biased) estimates of option value.
} 
and high intensity. ME2 $2_{\mathrm{k}}$ is estimated as the $\ln$ (Price) difference between a house with low (lower quartile) and one with high (upper quartile) intensity; this will be recognized as a difference in differences method of dealing with endogeneity.

Intuition for hypotheses 1 and 2

Assessed land value enters equations (5) - (7) in two ways: 1) interacted with

Deleted: $\mathscr{I}$

Deleted: The

Deleted: relationship between

interior area, FTG; and 2) in the denominator of intensity as measured by the LINT

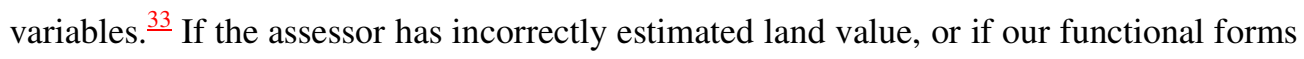
are incorrect, then our model may not correctly separate these two; as a result, option value won't be correctly measured.

An interesting case occurs Hypothesis 1 does not hold, meaning that we have not correctly controlled for land value in the standard hedonic model or in the use value portion of the option value model. Then it is possible that the LINT variables simply pick up, negatively, misspecification in land value, biasing estimates of option value downward. The bias is negative because assessed land value in the standard hedonic appears in the denominator of LINT. We conclude that we have not identified a high option value town when both $\mathrm{ME} 1_{\mathrm{k}}<0$ and $\mathrm{ME} 2_{\mathrm{k}}<0$. 
Figure 1 uses data for two towns to clarify the intuition behind our hypotheses.

The $\mathrm{X}$-access is our $\log$ of intensity variable (Lint $r$ ). The $\mathrm{Y}_{\text {-axis }}$ is the estimated marginal effect of Lint $r$ on our dependent variable, $\log$ of sales price after controlling

for the variables in equation (4). ${ }^{35}$ A local polynomial smoother (variable bandwidth, degree of polynomial $=2$ ) is used to estimate marginal effects over the range of Lint_r .

Figure 1 shows that the intensity variable has very different marginal effects in

$\underline{\text { the two towns. In Guilford there is a range of low intensity sales that have greater }}$ marginal effects on house value than a range of high intensity properties. Visually, it appears possible that $M E 1, M E 2>0$ in Guilford; i.e., conditions allow option value to be present for many low intensity properties. This is not the case in Southington, where low intensity sales have a lower marginal effect on value than high: i.e., ME1, ME2 $<0$. We conclude that Guilford may have option value whereas Southington does not. Statistical significance will be addressed when we present the data and empirical results. ${ }^{36}$

In Figure 2, we see that sales of high intensity properties in Guilford are interspersed with sales of low intensity properties. ${ }^{37}$ Our model is designed to find option value in exactly these cases: large new houses are sold in the same neighborhood as smaller older houses. In Southington, there is much more clustering of intensity in separate neighborhoods. This is likely due to the fact that Southington has a relatively large amount of developable land and has policies encouraging development of vacant land. Therefore, there is little need for high intensity properties to be redeveloped in the
Formatted: Font: (Default) Times

New Roman, 12 pt

Formatted: Justified, Indent: First line: 0.5 ", Line spacing: Double

Deleted: $y$

Formatted: Font: (Default) Times

New Roman, 12 pt
Formatted: Font: (Default) Times New Roman, 12 pt

Deleted: II
Formatted: Font: (Default) Times

New Roman, 12 pt

\footnotetext{
35 Details of the data and estimation methods will be presented below.

${ }^{36}$ In Section 5 we confirm that Guilford has positive option value and Southington does not.

${ }^{37}$ The sales in Figure 2 are for 2006 whereas the LPR smooth (Figure 1) uses data from the entire sample, 4 1994 through 2007 . An essential aspect of our model is that it is designed to deal with situations where the researcher does not have access to detailed spatial information, or has no knowledge of points of interest required to fully implement a spatial model.
}

\begin{tabular}{l} 
Formatted: Justified \\
\hline Formatted: Font: (Default) Times \\
New Roman, $10 \mathrm{pt}$
\end{tabular}


same neighborhoods as low intensity. It will always be more economical to develop

vacant land first, to avoid the cost of demolishing an existing property, a cost that

includes the sacrifice of the value of the existing vector of hedonic characteristics.

Statistical tests for the presence of option value at the town level

Deleted: $\mathbb{I}$

In this section, we develop statistical tests for our contention that $M E 1_{k}>0$ and $\mathrm{ME} 2_{\mathrm{k}}>0$ indicate the presence of option value. Options theory predicts positive relationship between option value and price volatility. We measure volatility, $\sigma_{\mathrm{j}}\left(\Delta \alpha_{\mathrm{t}, \mathrm{k}}\right)$, as the standard deviation of annual capital returns for each model $j$ and each town $k$, where $\Delta \alpha_{\mathrm{t}, \mathrm{k}}$ is the first difference of the estimated time coefficients between time $t$ and $t-1$.

Hypothesis 3: Option value is positively associated with town volatility.

If we find positive correlation, then we have increased confidence that option value can be distinguished from value due to the potential for positive NPV projects. In other words, we have addressed the issue raised by Bulan, Mayer and Somerville (2009).

We propose univariate and multivariate tests for the presence of option value. All tests are based on the following town-level variables that are associated with the presence of option value:

\section{Positive:}

- Drift in house prices within the town is positively associated with returns from developing to the optimal level. This is analogous to the dividend payout on a stock which can motivate the exercise of an option.

- Volatility of house prices within the town should be positively associated with option value.

- Household density (number of households per square foot of land area) indicates more need for redevelopment because less undeveloped land is available.

- Percent of land developed also indicates less undeveloped land is available.

- Price adjusted for structural characteristics (Adjusted price) - predicted price from a hedonic model with a constant set of characteristics for all towns. Cost to build (positively related to strike price) should be similar across towns, so higher price is 
associated with high option value. However, deep in the money options trade like stocks: the value of the option disappears. Therefore, we expect an inverted U-shape.

- House age increases option value by reducing a portion of the strike price: the foregone value of the existing structure. ${ }^{38}$

- Population growth increases demand for housing.

\section{Negative:}

- Per capita income $(P C I)$ after controlling for predicted price. Higher PCI indicates fewer liquidity constraints on exercise, faster exercise eliminates option value in two ways: 1) the property is near optimum configuration after redevelopment; 2) exercise increases supply, reducing the value of remaining options.

- New house sales as a percent of total sales. This is associated with a lot of vacant land, which reduces the value of the redevelopment option. ${ }^{39}$

- Percent change in land developed.

- Effective property tax rates reduce option value by increasing the cost of maintaining the new, more valuable property.

- Growth in the property tax levy in the town. Owners of more valuable property can expect further growth in property tax rates.

\section{Neutral:}

- Percent of housing stock that is owner occupied (Percent owner occupied). Theory applies equally to owner occupied and rental housing. We assume here that PCI is controlled, so any effect of owner occupancy on liquidity has been controlled.

We test for the predicted signs of this list of town variables. We hypothesize that towns with $M E 1_{k}>0$ and $M E 2_{k}>0$ should have significantly different values for these variables than other towns:

Hypothesis 4: Option value is associated with town characteristics in the direction predicted above.

\section{Data}

Our sample contains 162,454 single-family residential properties sold between 1994 and 2007 in 53 towns in Connecticut. The state of Connecticut represents a

\footnotetext{
38 The redevelopment option is an exchange option: the value of the existing vector of hedonic characteristics is exchanged for a new configuration.

${ }^{39}$ However, large increase in new construction can also imply that the land became relatively expensive. Spiegel (2001) develops a general equilibrium model which predicts that developers purchase land when it has a high expected return relative to homes in good condition, and develop and sell their land when it becomes relatively expensive.
} 
particularly good opportunity to study redevelopment because most of the land, especially in the most desirable locations, has been developed many years ago. The scarcity of vacant land with approvals for development suggests that option value for existing residential properties is important in Connecticut.

Our data is from the Warren Group, publishers of Bankers \& Tradesman, a business and real estate newspaper covering New England states (B\&T thereafter). B\&T collects the data via visits and electronic connections with Connecticut town halls. B\&T data contains all residential property transactions in the state of Connecticut. The dataset contain property characteristics at the time of sale: see Table 1 for description of relevant variables. We apply filters used in Clapp and Salavei (2010) to ensure data quality. ${ }^{40}$ When each model (Model 1 to 4) is estimated, the DFFITS procedure is applied to detect and remove influential observations in each town. An observation is classified as influential if its DFFITS value is larger than two times the square root of the number of parameters divided by the number of observations. ${ }^{41}$

Among 53 towns, the most active housing markets have more than 7,000 sales over the study period. The least active still records more than a thousand sales. As a whole, 53 towns have an average sale price of $\$ 462,677$, property age of 40 years, interior square footage of $1,853 \mathrm{sf}$, and lot size of $34,860 \mathrm{sf}$. The mean value of LINT is 0.293, indicating that structure value averages $34 \%(=\exp (.293)-1)$ higher than land

\footnotetext{
${ }^{40}$ As in Clapp and Salavei (2010), our sample is restricted to single-family residential properties with 1) warranty deeds, 2) sale price over $\$ 50,000,3$ ) interior footage over 300 sf and lot size between 1,500 sf and 10 acre, 4) more than three rooms and at least one bathroom, 5) structures built between 1901 and 2006, and 6) records of assessed building and land value. We also excluded those towns with not more than three sales in a year which might give an unreliable estimate of time effects and hence return volatility.

${ }^{41}$ See Belsley et al. (1980) for details. The DFFITS procedure removes about $5 \%$ of the observations from our sample.
} 
value. $^{42}$ There is a substantial variation in LINT: the mean of within town standard deviation is $0.608 .^{43}$ Lower intensity is not associated much with higher building age; for example, several towns have very low LINT while their building age is not particularly high. On the other hand, high intensity is found in towns with high building age, probably because of their relatively low land value. Overall, there seems to be little association between LINT and other hedonic variables, suggesting that intensity could provide additional information that helps single out the options component in the hedonic framework. The distributions of the hedonic and intensity variables by towns are summarized in Tables 2 and 3, respectively. The amount of option value embedded in each town may differ considerably, given the variations in LINT and other hedonic variables (e.g. Age) across towns.

\section{Results}

\subsection{Standard hedonic model (Model 1)}

Table 4 shows the results of estimating standard hedonic model as specified in equation (4) (Model 1) separately for each town. The average adjusted $\mathrm{R}^{2}$ for Model 1 is 85.2\%. The coefficients on hedonic characteristics are as expected for most towns. Previous literature finds that the house price should be decreasing in Age but increasing in $A g e^{2}$ : i.e., the rate of depreciation declines with age. ${ }^{44}$ We observe this relationship in most towns in Connecticut. Coefficient $\alpha_{8}$ on Age is negative and significant for 49 towns (92\%) and is insignificantly different from zero for 3 towns (6\%). Coefficient $\alpha_{9}$

${ }^{42}$ LINT' has a zero mean by construction; see Equation (5).

| ${ }^{43}$ This suggests that assessor's in Connecticut carefully analyze each property.

${ }^{44}$ Dye and McMillen (2007) and many others have documented this pattern.
Formatted: Font: 12 pt, English (U.S.)

Formatted: Font: Not Italic 
on $\mathrm{Age}^{2}$ is positive and significant for 45 towns (85\%), insignificantly different from zero for 5 towns (9\%), and negative and significant for 3 towns $(6 \%) .{ }^{45}$

The equation also includes variable Bath2or 3 that equals one for houses with 2 or 3 bathrooms and variable Bath $3 p$ that equals one when the house has more than three bathrooms, an indicator of large, luxurious houses ("mansions"). We expect and find that the coefficients on both of these variables are positive for most towns. Coefficient $\alpha_{11}$ on Bath2or3 is positive and significant for 52 towns (98\%) and is insignificantly different from zero for 1 town (2\%). Coefficient $\alpha_{10}$ on Bath3p is positive and significant for 40 towns $(80 \%)$ and is insignificantly different from zero for 10 towns $(20 \%) .{ }^{46}$ The average coefficient for Bath3p adds $11.4 \%$ (=exp(.108)-1) to value, compared to $6.0 \%$ for Bath2or3, indicating some success in capturing the mansion effect.

House price should be increasing in lot size (Lotsf), but at a decreasing rate. Therefore, we expect $\alpha_{6}$ to be positive (coefficients on Lotsf), and $\alpha_{8}$ to be negative (coefficients on $L o t s f^{2}$ ). We find evidence consistent with this prediction for most towns. Coefficient $\alpha_{6}$ on Lotsf is positive and significant for 50 towns (94\%), negative and significant for 2 towns (4\%) and insignificantly different from zero for 1 town (2\%). Coefficient $\alpha_{7}$ on Lotsf $f^{2}$ is negative and significant for 45 towns (85\%), is insignificantly different from zero for 6 towns $(11 \%)$ and is positive and significant for 2 towns (4\%), the same 2 towns that have negative and significant coefficients for Lotsf. Thus, the

\footnotetext{
${ }^{45}$ Hartford is the only town for which significant coefficients on Age and $\mathrm{Age}^{2}$ are of exact opposite direction than expected. In Hartford, the coefficients indicate that property value increases up to only four years, then decreases. Thus, the generally negative effect of age holds even in Hartford.

${ }^{46}$ Coefficient $\alpha_{10}$ could not be calculated for three towns due to the lack of observations.
} 
significant effect of Lotsf is always positive beyond some small value. Overall, the marginal effect of Lotsf, evaluated at mean Lotsf, is positive for 51 towns (96\%).

Similarly, house price should be increasing in interior square footage $(F t g)$, but at a decreasing rate. For houses at the lower land value quartile $\left(L V_{l}\right)$, coefficient $\alpha_{4}$ on Ftg is positive and significant for 51 towns (96\%), and 33 towns (62\%) have negative and significant coefficient $\alpha_{5}$ on Footage $e^{2}$.

Table 4, Panel B confirms Hypothesis 1: at a given value of footage (the mean), the capitalized value of rents increases with higher land value quartiles. The increase in $M E \_L V_{q}$ (equation (10)) is significant at the $1 \%$ level according to t-test and Wilcoxon signed rank test across the towns. However, the effect of land value on footage is insignificant in many towns as indicated by Panel A: the interaction terms between Ftg and other land value quartiles $\left(L V_{2}, L V_{3}\right.$, and $\left.L V_{4}\right)$ are mostly insignificant - for example, coefficients on $F \operatorname{tg} \times L V_{3}$ and $\mathrm{Ftg}^{2} \times L V_{3}$ are insignificant for 37 towns (70\%) and 38 towns (72\%), respectively. ${ }^{47}$ This suggests a potential downward bias in ME1 and ME2 since they may capture land value not correctly captured in equation (4). If they are greater than zero, then we have a conservative estimate of option value.

\subsection{Option-based hedonic models (Model 2-4)}

Table 5 compares the marginal effects of properties in the lowest quartile of intensity for Models 2 to 4 . Table 5, Panel A shows estimates of coefficient $\beta_{0}$ on variable LINT_Z, $\beta_{1}$ on variable LINT25' and $\beta_{2}$ on variable LINTG75' of Model 2 (equation 6) and calculates the marginal effects, ME1 and ME2, based on equations 11a

${ }^{47}$ Land value appears to be captured by the $L V_{2}, L V_{3}$, and $L V_{4}$ dummies. Table 4 , panel A indicates that house value increases by about $8 \%, 15 \%$ and $25 \%$ at the $2^{\text {nd }}, 3^{\text {rd }}$ and $4^{\text {th }}$ quartile dummies, with most towns having significant effects. 
and $11 \mathrm{~b}{ }^{48}$ Among the 53 towns, 12 have significantly positive ME1 and 24 have significantly negative ME1 ${ }^{49}$ For ME2, 11 show significantly positive values and 29 show significantly negative values. These results suggest that a majority of towns does not have much option value. As suggested by Hypothesis 1, the significant negative values are likely due to variation in land value that is captured negatively in the LINT variables. ME1 and ME2 for positive option value towns are highlighted in bold. ${ }^{50}$ For these towns the mean (median) ME1 is 32\% (29\%) and the mean (median) ME2 is $29 \%$ $(24 \%){ }^{51}$

Hypothesis 2 predicts that towns with positive ME2 - the lowest quartile of intensity adds more to house value than the highest quartile, even though the latter are likely to be better located - should also be the towns with positive ME1. This hypothesis is confirmed, with the same 11 towns showing significantly positive ME1 as well as ME2 in Model 2. There is only exception, for which ME1 $>0$ and significant but ME2<0 and insignificant.

Table 5, Panel B shows ME1 and ME2 for Model 3, which allows the intensity variables to interact with Age and $\mathrm{Age}^{2}$; see equation (7) for the formula used. The results for marginal effects for Model 3 (equations 12a and 12b) are very similar to those for Model 2 - most of the towns do not have high option value. We find that ME1 is negative and significant for 26 towns but positive and significant for 10 towns, while ME2 is negative and significant for 28 towns but positive and significant for 10 towns. Among positive option value towns, the mean (median) ME1 is $31 \%$ (25\%) and that for ME2 is

\footnotetext{
${ }^{48}$ For brevity, we do not report coefficients on standard hedonic characteristics in Table 5.

${ }^{49} \mathrm{We}$ used a standard F-test of the significance of a linear combination of coefficients.

${ }^{50}$ Recall that positive option value towns are those for which ME1>0 and significant and 5\% level and ME2 $>0$ and significant at $5 \%$ level.

${ }^{51}$ We translate ME1 and ME2 into percentage effects using exp(coeff)-1.
} 
29\% (21\%). The ten towns identified to have positive and significant ME2 are exactly those with positive and significant ME1, so Hypothesis 2 is again confirmed.

Figure 3 maps the 53 towns with enough data to estimate our model. The $10^{4}$

Formatted: Justified, Indent: First line: $0.5 "$, Line spacing: Double

towns found to have high option value are highlighted. The figure reveals that the high option value towns are all in Fairfield County or along the Long Island shoreline. I.e., they are clustered in the most desirable parts of Connecticut. We find no significant option value at the town level in, for example, Greenwich and Westport, which are located in highly desirable areas - most options are likely already exercised in these towns. $^{52}$

Table 5, Panel C shows results of estimating Model 4, which further relaxes Deleted: 9

Model 3 by allowing the effects of the intensity variables to vary before and after year 2000 (see equation (8) for the formula used). We find that the marginal effects as described in equations (13a) and (13b) have changed over time. First, more towns are identified to have high option value in the latter period: before 2000, 7 (10) towns have significantly positive ME2 (ME1); after 2000, 13 (11) towns have significantly positive ME2 (ME1). Second, among positive option value towns, the median ME1 increases from $27.6 \%$ to $37.1 \%$. The same holds true for median ME2, which increases from $14 \%$ to $33 \%$. The mean for ME1 decreases slightly from $34.4 \%$ to $33.9 \%$; the mean for ME2 increases from $31.6 \%$ to $34.2 \%$. This suggests that option value may change with interest rates, volatilities, underlying asset prices, strike prices, etc.

Hypothesis 2 is generally supported in Model 4. Before 2000, seven towns share significantly positive ME1 and ME2. Three towns have positive signs for both ME1 and

$\frac{52 \text { If we had detailed spatial data in each town, then we might be able to find some neighborhoods with }}{\text { option value, as Clapp and Salavei (2010) did in Greenwich. }}$

Formatted: Justified 
ME2 but their ME2 is not significant. After 2000, significantly positive ME1 and ME2 are found in 11 towns. There are only two exceptions, for which ME1 $>0$ and ME2 $>0$ but with ME1 being not significant.

To summarize, we find that almost $20 \%$ of towns in CT have positive OV. Option value for properties in lowest quartile of intensity in positive option value towns has a mean value of $32 \% .{ }^{53}$ Towns with positive and significant ME1 generally have positive and significant ME2.

\subsection{Price volatility and other determinants of option value}

\subsubsection{Univariate analysis: comparison of positive and zero option value towns}

In this section we test whether characteristics of towns with positive value of option to redevelop identified using Models 3 and 4 are consistent with real options theory as predicted by hypotheses 3 and 4 .

The main objective of this section is to distinguish option value from redevelopment that occurs whenever the net present value (NPV) of the redeveloped property is greater than zero: see Bulan, Mayer and Somerville (2009) for discussion of this point. Increases in the volatility of the underlying stochastic process for the price of the house should increase option value but decrease NPV. Therefore, if we find that our estimate of option value is positively related to price volatility this would be a direct test of the contention that we can measure option value with the intensity variable (i.e. hypothesis 3). For each model we estimate town level volatility using the standard deviation of the annual capital return as measured by changes in the time coefficients for each town. We estimate the mean value of volatility to average $7.62 \%$ across all models

\footnotetext{
${ }^{53}$ This value is obtained by averaging ME1 and ME2 for positive OV towns across models.
} 
(see Table 6, Panel A). Consistent with predictions of hypothesis 3, we find that the correlation between volatility and option value is positive and significant for all models, except for Model 4 before $2000 .^{54}$ This result is robust to using both ME1 and ME2.

Table 7, Panel A shows characteristics of positive option value towns compared to zero option value towns. ${ }^{55}$ Positive option value towns are those for which ME1>0 and ME2>0. We find that consistent with real options theory, volatility for positive option value towns (median=11.34\%) is higher than for zero option value towns (median $=6.71 \%$ ) and the difference is statistically significant. ${ }^{56}$

In addition to analyzing difference in volatility between positive and zero option value towns, in Table 7, Panel A we compare other town characteristics as discussed in relation to hypothesis $4 .{ }^{57} \mathrm{We}$ find that positive option value towns have higher mean and median drift in house prices than zero option value towns. Median (mean) drift equals $7.36 \%(7.20 \%)$ for positive option value towns compared with $6.20 \%(6.43 \%)$ for zero option value towns. Median price adjusted for structural characteristics, Adjusted price, is higher for positive option value towns $(\$ 290,869)$ than for zero option value towns $(\$ 219,538)$. Both the effective property tax and the growth in the tax levy are lower for positive option value towns. The median effective property tax rate is $1.25 \%$ for positive option value towns and $1.57 \%$ for zero option value towns. The tax rate increased by $4.97 \%$ for positive option value towns compared with $6.05 \%$ increase for zero option

\footnotetext{
${ }_{55}^{54}$ Option value equals ME1 or ME2 for positive option value towns and zero otherwise.

${ }^{55}$ In Tables 7, 8 and 9 we omit results for Model 2 for brevity. Results for Model 2 are very similar to results for Model 3.

${ }_{56}^{56}$ Volatility is estimated from Model 3 time dummy coefficients.

${ }^{57}$ Please see Table 1 for precise definitions of all variables.
} 
value towns. This result is consistent with findings of Mayer and Somerville (2000) that extensive regulation reduces residential construction. ${ }^{58}$

Positive and zero option value towns do not differ with respect to household density, percent of land developed, house age, population growth, PCI, new house sales, percent change in land developed and percent owner occupied. The result for the latter variable is as expected. A potential reason why household density does not differentiate positive and zero option value towns is because household density is high both in high crime and low income urban towns in CT (such as New Haven and Hartford) where option value is near zero and in desirable locations with high option value. The insignificant result for percent land developed, percent change in land developed, new house sales is likely explained by the fact that we do not control for within town location. It is possible that most desirable locations are already developed and option value increases only for already developed land. Age is a noisy variable that often does not reflect major renovations and can capture better quality of construction of older properties.

In Table 7, Panels B and Panel C we separately analyze periods before 2000 and after 2000, respectively. Most results are similar to those in Panel A, except for drift and volatility. Before 2000 positive option value towns do not differ from zero option value towns with respect to volatility and drift of house prices. A possible explanation for this finding is that there were fewer sales in this time period and for some towns our estimate of volatility and drift might be noisy. Results after 2000 reported in Table 7, Panel C are consistent with Model 3 results reported in Table 7, Panel A. After 2000, positive option

\footnotetext{
${ }^{58}$ Specifically, they find that mean starts can be up to 45 percent lower in cities that have more extensive regulation.
} 
value towns have higher volatility (median $=13.15 \%$ ) compared with zero option value towns in this period (median=5.62\%). Median volatility for positive option value towns increased from $4.50 \%$ in before 2000 period to $13.15 \%$ in post 2000 period.

Overall, univariate analysis for Model 3 and Model 4 after 2000 supports real option theory and hypothesis 3 and finds that positive option value towns have higher volatility than towns without redevelopment option. This result is inconsistent with NPV framework. Univariate analysis for Model 3 and Model 4 after 2000 supports hypothesis 4 for drift in house price, adjusted price, effective property tax rate, and growth in the property tax levy. For Model 4 before 2000 univariate analysis supports hypothesis 4 for adjusted price, effective property tax rate, and growth in the property tax levy.

\subsubsection{Multivariate analysis of option value determinants}

In this section we test hypotheses 3 and 4 in a multivariate setting. First, we use logit model to examine if the likelihood of a town having positive option value is associated with town characteristics as predicted. We standardize all variables on the right hand side to a mean of zero and a standard deviation of 1 .

Table 8 shows separate analysis for positive and zero option value towns for Model 3, Model 4 before 2000 and Model 4 after 2000. In the first specification, we include all of the variables that were identified to be important determinants of option value in previous section using univariate tests. We find that volatility is positively associated with the likelihood of positive option value for Model 3 and Model 4 after 2000 in multivariate setting. However, the coefficient on volatility is insignificant in Model 4 before 2000. Drift in house prices has positive coefficient for Model 3 and Model 4 after 2000, but is not significant. Adjusted price has negative and significant 
coefficient, which is contrary to our expectation of a positive relation between adjusted price and option value. However, the relation between option value and adjusted price is hypothesized to be u-shaped. Therefore, we include a square term of adjusted price in specification 2. As expected, we find positive coefficient on adjusted price and negative coefficient on its square term. ${ }^{59}$ In all models, effective property tax rate is negatively associated with the likelihood of positive option value. Growth in the property tax levy has negative coefficient, as expected, but it is significant only for Model 4 before 2000 . In results not shown, we include all other characteristics of towns (one at a time) to specifications 1 and 2. Consistent with our univariate analysis, none of the other variables are significant. Overall, logit analysis of the likelihood of positive option value supports hypotheses 3 and 4 for volatility, drift, adjusted price, and property tax for the entire sample period of 1994-2007 and the period after 2000.

Next we estimate a tobit model with option value as a dependent variable, which equals ME1 for positive OV towns and zero otherwise (Table 9). ${ }^{60}$ For example, for Model 3 ten towns will have positive option value and 42 will have option value equal to zero. Therefore, we use a tobit model with left censoring; this allows the magnitude of ME1 $>0$ to be associated with the explanatory variables. All results in Table 9 are very similar to those in Table 8 . This is especially comforting given that our dependent variable has substantial estimation error in edition to censoring. The only difference is that the coefficient on volatility becomes more significant for Model 3 and Model 4 after 2000, and the coefficient on drift of house price becomes significant in specification 1a. As in the case of logit model, we tried alternative specifications adding one at a time all

\footnotetext{
${ }^{59}$ These coefficients are significant for Model 3 and Model 4 after 2000, but not for Model 4 before 2000.

${ }^{60}$ Our results are also robust to using a more restrictive definition of positive option value towns, by replacing ME1 with ME2 in all definitions.
} 
other variables reported in Table 7 to specifications 1 and 2 but do not find any of them to be statistically significant.

\section{Relationship to prior literature}

Our paper differs from most of prior literature in how we estimate the value of the option to redevelop in the context of a hedonic pricing model. Our results are closely related to findings of Quigg (1993), which, to the best of our knowledge, is the only other paper that values a real option as an addition to intrinsic value. Quigg estimates the value of the option to develop for different types of vacant land in Seattle for the period of 1976-1979. Quigg finds that the value of option to develop low-density residential real estate, the sample most directly comparable to ours, ranges from $1 \%$ to $11 \%$ with a mean of $5.75 \%$.

Our comparable estimates for positive option value towns, measured by ME2>0 and statistically significant, ranges from $28.7 \%$ to $31.6 \%$ (Table 5). Since less than $20 \%$ of the towns have positive option value, this suggests that the average town has option value of about 6\%, well within the range estimated by Quigg. Note that this estimate is relevant only for the lowest quartile of intensity, the part of our sample most similar to Quigg's vacant land. After adjustment for the conservative (downward) bias in our estimates, the average option value is at most $8-9 \% .^{61}$

Several differences between our method and Quigg's might explain the wider range of estimates we obtain. First, Quigg's model applies to vacant land, a special case of our model when intensity equals zero. Second, Quigg assumes that all developed

${ }^{61}$ Our tests of H1 suggest that the LINT coefficients are negatively biased by misspecification of land value. The average of negative estimates is about $10 \%$, giving us a rough estimate of $2.0 \%$ to $2.5 \%$ downward bias for the average town. 
properties are at their optimal intensity for hedonic estimation of the value of the underlying asset. This omits any consideration of additive option value, our intensity variable. Third, Quigg's option value estimates rely on multiple assumptions and is highly sensitive to them. ${ }^{62}$ By way of contrast, our method is data driven.

Our paper is also related to the stream of literature that estimates the impact of volatility on property value.$^{63}$ Consistent with real options theory prior literature finds that there is a positive relation between volatility and real estate prices; presumably this is due to a positive association between prices and option value. Our paper is the first to estimate the amount of option value embedded in developed properties. This allows us to test directly the association between option value and volatility and other town characteristics.

\section{Conclusions}

This paper develops a new approach to empirically estimating the value of the option to redevelop residential real estate. Our analysis is guided by a generalization of the standard hedonic model to account for the option value of reconfiguring hedonic characteristics. We test this model by adding a non-linear intensity variable to capture the value of the option to redevelop; intensity is measured as a ratio of assessed structure value to assessed land value. Low intensity corresponds to high redevelopment potential. Intensity is distinct from the vector of hedonic characteristics because it is decreasing in land value and therefore lot size. Moreover, it correctly captures low redevelopment potential of large houses and of any house on a low-valued lot. For each town we

\footnotetext{
${ }^{62}$ For example, Quigg makes assumptions about risk-adjusted drift parameters of price and building costs, interest rates, development cost scale parameter, annual standard deviation of development costs, etc.

${ }^{63}$ See Sivitanidou and Sivitanides (2000), Holland, Ott, and Riddough (2000), Downing and Wallace (2001), Cunningham (2006), Cunningham (2007), and Bulan, Mayer and Somerville (2009) among others.
} 
estimate several specifications of option-based hedonic models that include various functions of intensity and its interaction with other variables.

We pose and test four sets of hypotheses. First, we develop conditions under which land value is properly captured by hedonic vector, implying that the marginal affect of our intensity variable can be used to estimate the value of option to redevelop. Second, we identify option value separately from land value and structure value when a dummy for the lowest quartile of intensity (smaller, older houses) adds significantly more to house value than the upper quartile (larger, newer houses). Third, options theory predicts a positive relation between option value and volatility. Fourth, we develop predictions for the relation between town social and economic characteristics and option value.

Using a sample of over 162,000 sales of residential real estate in the state of Connecticut over the period 1994 through 2007 we find positive option value (our second hypothesis) for nearly $20 \%$ of the towns with the mean positive value equal to about $32 \%$. We find support for all four sets of hypotheses. The relationship between option value and volatilities is found to be positive, with virtually all of the effect concentrated in the boom period from 2001 - 2007. This is consistent with the well known nonlinearity of option value: at-the money options are sensitive to changes in parameters whereas other options are much less sensitive. We also find that towns with higher price drift and lower taxes have higher option value.

We deal with endogeneity concerns (i.e., the simultaneous determination of our intensity variable and the use value term) in three ways: 1) Our option value variable is based on lagged values; 2) identification of option value follows from our nonlinear 
model specification; 3) we use a difference in differences method of dealing with endogeneity. Misspecification of land value in the hedonic model implies conservative (i.e., downwardly biased) estimates of option value. This supports our claim that we can identify properties with substantial option value, and estimate a lower bound on the amount of option value. 


\section{References:}

Abel, A.B. 1983. Optimal Investment Under Uncertainty. American Economic Review 73: 228-33.

Bourassa, S., M. Hoesli, D. Scognamiglio, and S. Zhang. 2011. Land Leverage and House Prices. Regional Science and Urban Economics, 41 (2), 134-144.

Belsley, D.A., E. Kuh and R.E. Welsch. 1980. Regression diagnostics: identifying influential data and sources of collinearity. New York: Wiley.

Bostic, R. , Longhofer, S., Redfearn, C., 2007. Land leverage: decomposing home price dynamics. Real Estate Economics 35, 183-208.

Brueckner, J., and S. Rosenthal. 2006. Gentrification and neighborhood housing cycles: Will America's future downtowns be rich? Working paper.

Bulan, L., C. Mayer, and C. T. Somerville. 2009. Irreversible investment, real options, and competition: Evidence from real estate development. Journal of Urban Economics 65(3): 237-251.

Capozza, D., and Y. Li. 1994. The Intensity and Timing of Investment: The Case of Land. American Economic Review 84 (4): 889-904.

Capozza, D. and G. Sick. 1994. The Risk Structure of Land Markets. Journal of Urban Economics 35: 297-319.

Childs, P., S.H. Ott and T.J. Riddiough. 2002. Optimal Valuation of Claims on Noisy Real Assets: Theory and an Application. Real Estate Economics 30: 415-444.

Ching, S., and Y. Fu .2003. Contenstability of the Urban Land Market: An event study of Hong Kong Land Auctions." Regional Science and Urban Economics 33, 695720 .

Clapp, John M., Jyh-Bang Jou and Tan Lee. 2011. "Hedonic Models with Redevelopment Options under Uncertainty." Forthcoming, Real Estate Economics. Draft paper at http://papers.ssrn.com/sol3/papers.cfm?abstract_id=1048801.

Clapp, J.M, and K. Salavei. 2010. Hedonic Pricing with Redevelopment Options: A New Approach to Estimating Depreciation Effects. Journal of Urban Economics 67 (3): 362-377.

Cunningham, C. R. 2006. House Price Uncertainty, Timing of Development, and Vacant Land Prices: Evidence for Real Options in Seattle. Journal of Urban Economics 59: $1,1-31$.

Cunningham, C. R., 2007. Growth Controls, Real Options and Land Development. 
Review of Economics and Statistics, LXXXIX(2), 343-358.

Davis, M., Heathcote, J., 2007. The price and quantity of residential land in the United States. Journal of Monetary Economics 54, 2595-2620.

Davis, M., Palumbo, M., 2008. The price of residential land in large U.S. cities. Journal of Urban Economics 63, 352-384.

Dixit, A. and Pindyck, 1994. Investment under uncertainty. Princeton, NJ, Princeton University Press.

Dixit, A. K. 1989. Entry and Exit Decisions under Uncertainty. Journal of Political Economy, 97(3), 620-638.

Downing, C. and N. Wallace. 2001. A Real Options Approach to Housing Investment. University of California Berkeley working paper.

Dye, R.F. and D.P. McMillen. 2007. Teardowns and Land Values in the Chicago Metropolitan Area. Journal of Urban Economics 61: 45-63.

Grenadier, S.R. 1996. The strategic exercise of options: development cascades and overbuilding in real estate markets. Journal of Finance 51(5), 1653-1679.

Grenadier, S.R. 1999. Information Revelation through Option Exercise. Review of Financial Studies 12, 95-130.

Grenadier, S.R. 2002. Option Exercise Games: An Application to the Equilibrium Investment Strategies of Firms. Review of Financial Studies 15, 691-721.

Harding, J., Sirmans, C.F. and Rosenthal, S.S., 2007. Depreciation of Housing Capital, Maintenance and house price inflation: Estimates from a repeat sales model. Journal of Urban Economics 61 (2): 193-217.

Holland, A., S. Ott and T. Riddiough. 2000. The Role of Uncertainty in Investments: An Examination of Competing Investment Models using Commercial Real Estate Data. Real Estate Economics 28: 33-64.

Malpezzi, S., Ozanne, L., Thibodeau, T.G., 1987. Microeconomic estimates of housing depreciation. Land Economics 63, 372-385.

Majd, S. and R. S. Pindyck. 1987. Time to Build, Option Value, and Investment Decisions. Journal of Financial Economics 18: 7-27.

Mayer C. J., and C. T. Somerville. 2000. Land Regulation and New Construction. Regional Science and Urban Economics, 30 639-662.

McDonald, R. and D. Siegel. 1986. The Value of Waiting to Invest. Quarterly Journal of Economics 101(4): 707-728. 
Munneke, H. J. 1996. Redevelopment Decisions for Commercial and Industrial Property. Journal of Urban Economics 39(2): 229-253.

Quigg, L. 1993. Empirical Testing of Real Option-Pricing Models. Journal of Finance 48(2): 621-640.

Rosen, S. 1974. Hedonic Price and Implicit Markets: Product Differentiation in Pure Competition. Journal of Political Economy 82: 34-55.

Rosenthal S. S. 2008. Old Homes, Externalities and Poor Neighborhoods: A Model of Urban Decline and Renewal. Journal of Urban Economics 63(3): 816-840.

Rosenthal, S. and R. Helsley. 1994. Redevelopment and the Urban Land Price Gradient. Journal of Urban Economics 35: 182-200.

Sick, G. 1990. Capital Budgeting with Real Options. Monograph Series in finance and Economics, Monograph 1989-3 New York, NY.

Sivitanidou, R. and P. Sivitanides. 2000. Does the Theory of Irreversible Investments Help Explain Movements in Office-Commercial Real Estate? Real Estate Economics 28(4): 623-662.

Spiegel, M. 2001. Housing Return and Construction Cycles. Real Estate Economics, 2001, 29(4), 521-551.

Titman, S. 1985. Urban Land Prices under Uncertaint. American Economic Review 75(3): 505-514.

Wang, K. and Y. Zhou. 2006. Equilibrium Real Options Exercise Strategies with Multiple Players: The Case of Real Estate Markets. Real Estate Economics 34 (1): $1-49$.

Williams, J. T. 1991. Real Estate Development as an Option. Journal of Real Estate Finance and Economics 4(2): 191-208.

Williams, J. T. 1993. Equilibrium and options on real assets." Review of Financial Studies. 6 (4): 825-850.

Williams, J. T. 1997. Redevelopment of Real Assets. Real Estate Economics 25(3): 387407.

Wu, J. and S. Cho. 2007. The Effect of Local Land Use Regulation on Urban Development in the Western United States. Regional Science and Urban Economics 37, 69-86. 
Figure 1: Marginal effect of intensity on log of sales price using local polynomial smoother

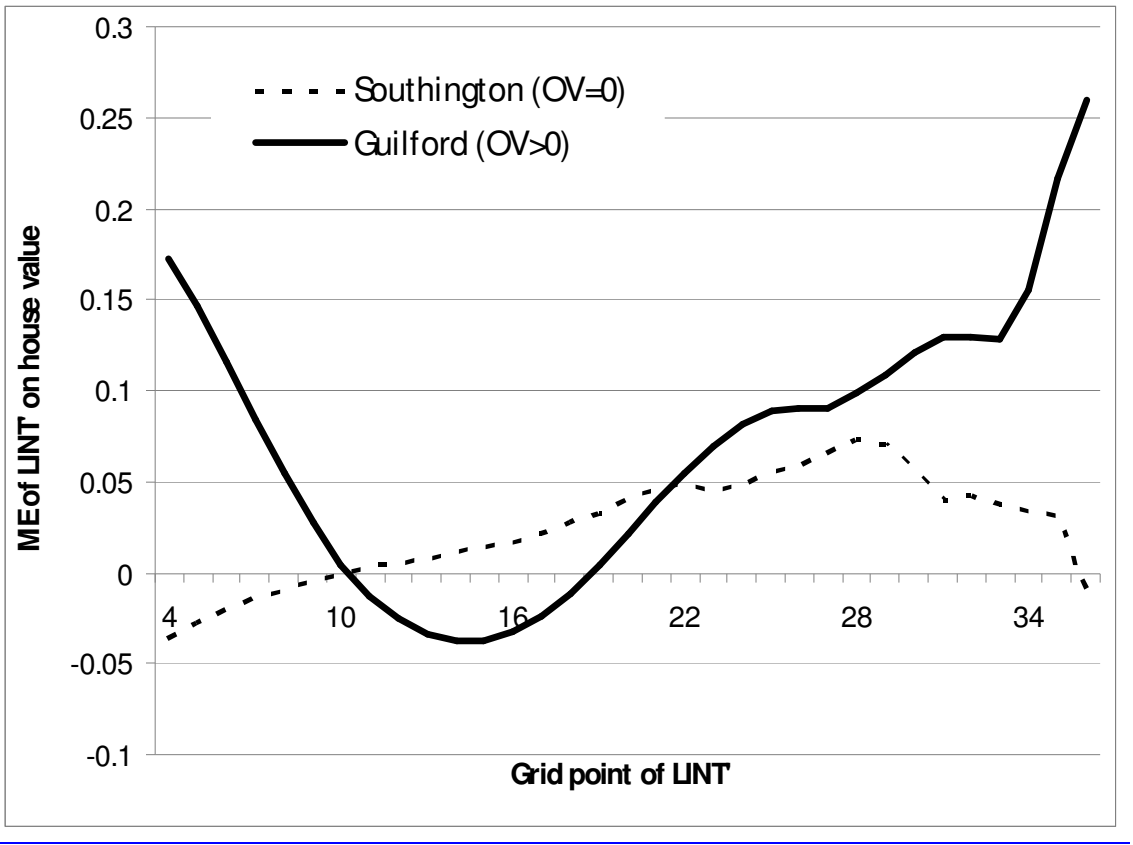

The X-access is the $\log$ of intensity variable (Lint_r). The Y-axis is the estimated marginal effect of Lint $r$ on our dependent variable, $\log$ of sales price after controlling for the variables in equation (4). Marginal effect is estimated using a local polynomial smoother for two towns: Guilford and Southington. Guilford has positive option value and Southington has zero option value based on Models (2-4). Guilford has much more dispersion in Lint $r$, so needs a bigger bandwidth. Therefore, $\mathrm{X}$-axis has different range for the two towns:

$\underline{\mathrm{SD}}$

Range

$\underline{\text { Min }}$

Max

\begin{tabular}{|c|c|}
\hline Southington & Guilford \\
\hline$\underline{0.42}$ & $\underline{0.54}$ \\
\hline 3.9 & 6.7 \\
\hline-1.15 & -2.95 \\
\hline 2.75 & $\underline{3.74}$ \\
\hline
\end{tabular}


Figure 2: Intensity in Guilford (top) and Southington (below)
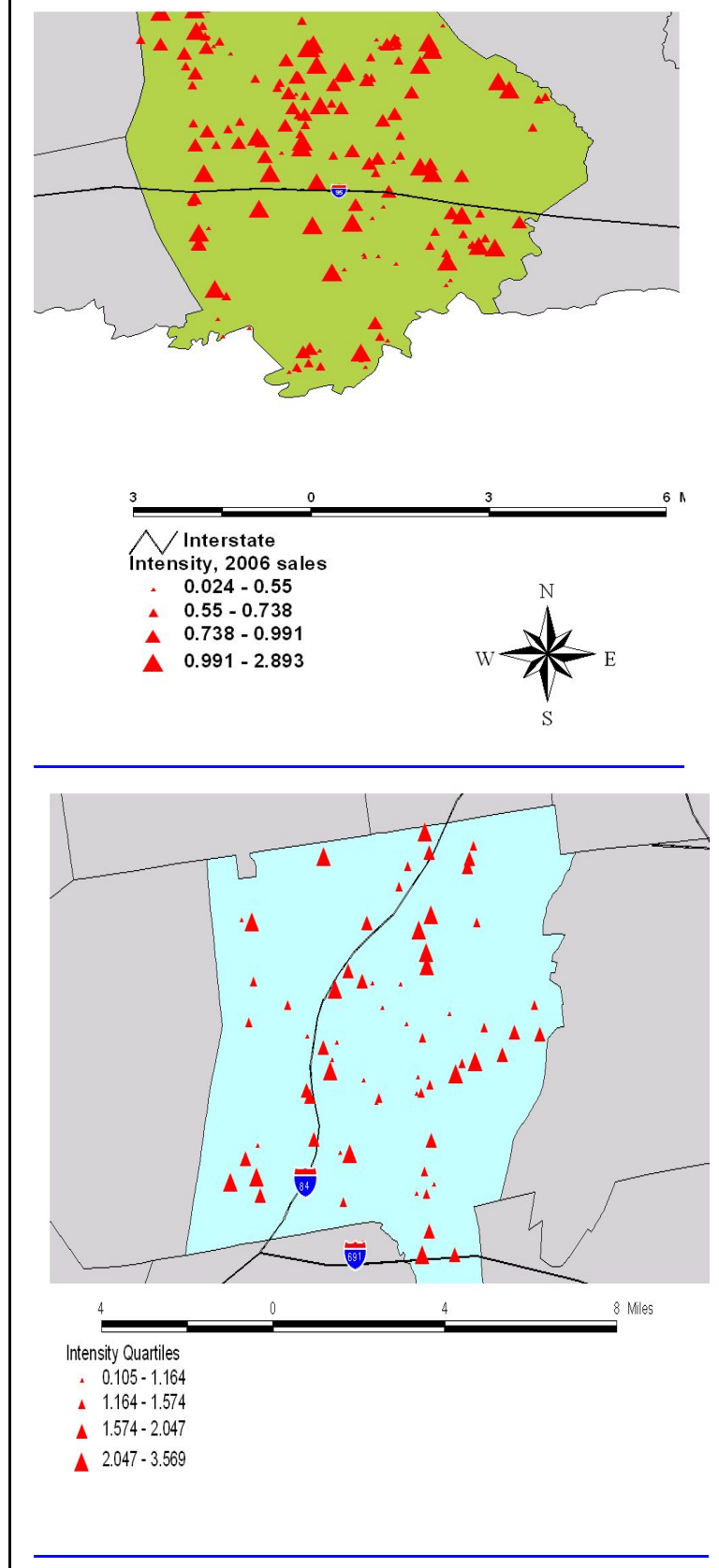

Formatted: Font: (Default) Times New Roman, 12 pt 
Figure 3: The 53 towns subject to analysis and 10 towns with significantly high option value (dark)

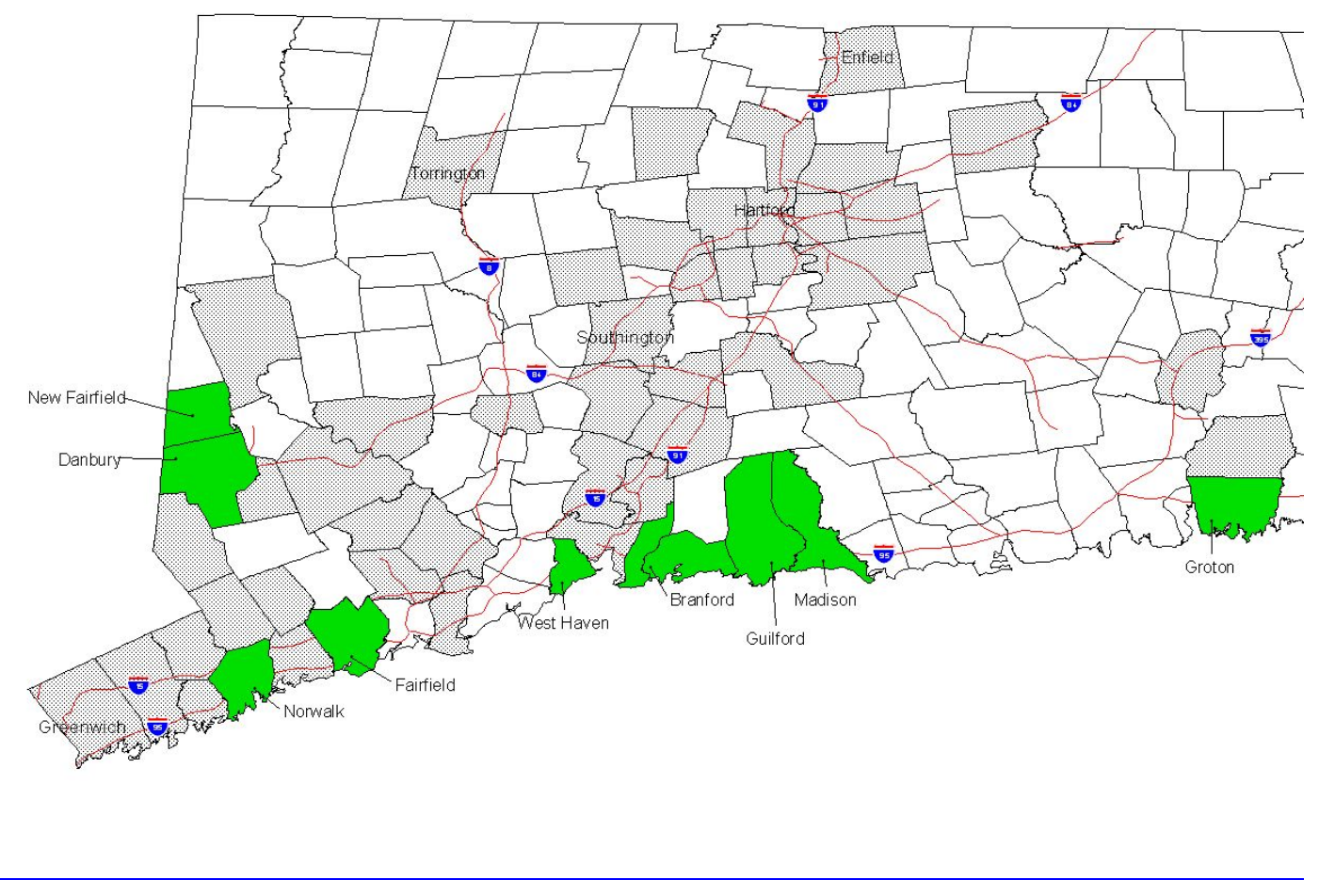


Table 1: Variable description and source of data

\begin{tabular}{|c|c|c|}
\hline Variable Name & Variable Description & $\begin{array}{l}\text { Data } \\
\text { Source }\end{array}$ \\
\hline \multicolumn{3}{|l|}{ Standard hedonic } \\
\hline PRICE & Price at which the property was sold. & $\mathrm{B} \& \mathrm{~T}$ \\
\hline AGE & Age of the property in years. & B\&T \\
\hline BATH2OR3 & Equals one if the property has two or three bathrooms; zero otherwise. & B\&T \\
\hline BATH3P & Equals one if the property has more than three bathrooms; zero otherwise. & $\mathrm{B} \& \mathrm{~T}$ \\
\hline FTG & Interior square footage of the property at the time of sale. & $\mathrm{B} \& \mathrm{~T}$ \\
\hline LOTSF & Size of the property's lot in square feet. & $\mathrm{B} \& \mathrm{~T}$ \\
\hline YEAR $_{t}$ & Equals one if the year in which the property was sold is year $t$; zero otherwise. & Calculated \\
\hline B00 & Equals one if the property was sold in or before year 2000; zero otherwise. & Calculated \\
\hline A00 & Equals one if the property was sold after year 2000; zero otherwise. & Calculated \\
\hline LV & Assessed value of the lot. & B\&T \\
\hline $\mathrm{LV}_{\mathrm{q}}$ & $\begin{array}{l}\text { Equals one when the residuals from regressing } \ln (\mathrm{LV}) \text { on } \ln (\mathrm{LOTSF}) \text { is in its } \mathrm{q}^{\text {th }} \\
\text { quartile; zero otherwise }\end{array}$ & Calculated \\
\hline \multicolumn{3}{|l|}{ Options related } \\
\hline INTENSITY & Assessed value of the building divided by the assessed value of the lot. & $\mathrm{B} \& \mathrm{~T}$ \\
\hline LINT & $\begin{array}{l}\text { Natural logarithm of INTENSITY, with its } 2 \text { nd percentile by town assigned to } \\
\text { any properties below the } 2 \text { nd percentile. }\end{array}$ & Calculated \\
\hline LINT' & The de-trended component of LINT. & Calculated \\
\hline LINTZ' & Equals ten when LINT' is at its bottom $2 \%$ values; zero otherwise & Calculated \\
\hline LINT25 & Equals ten when LINT' is at its bottom $25 \%$ values; zero otherwise & Calculated \\
\hline LINTG75, & Equals ten when LINT' is at its top $25 \%$ values; zero otherwise & Calculated \\
\hline \multicolumn{3}{|c|}{ Town characteristics } \\
\hline $\begin{array}{l}\text { Percent of land } \\
\text { developed }\end{array}$ & $\begin{array}{l}\text { Percent of developed land in } 2006 \text { for each town is obtained from The } \\
\text { Connecticut Economy (2010), based on data from the Center for Land Use } \\
\text { Education and Research (CLEAR), University of Connecticut that uses satellite } \\
\text { images. Water, } 3 \text { types of wetland, and utility corridors are classified as land not } \\
\text { available for development. Developed land includes developed land plus } \\
\text { maintained-turf-and-grass; undeveloped land includes other grasses, agricultural } \\
\text { fields, deciduous forest, coniferous forest, and barren. }\end{array}$ & CLEAR \\
\hline $\begin{array}{l}\text { Percent change in } \\
\text { land developed }\end{array}$ & Percent change in percent of land developed from 1985 to 2006. & CLEAR \\
\hline $\begin{array}{l}\text { Drift in house } \\
\text { price }\end{array}$ & $\begin{array}{l}\text { Annualized rate of change of adjusted price for model } j \text { for each town } k \text { between } \\
\text { time } t \text { and } t+1 \text {. }\end{array}$ & Calculated \\
\hline Adjusted price & $\begin{array}{l}\text { Price predicted by model } j \text { for each town } k \text { for a median property across all } \\
\text { towns. }\end{array}$ & Calculated \\
\hline $\begin{array}{l}\text { Volatility of house } \\
\text { prices }\end{array}$ & $\begin{array}{l}\text { Volatility, } \sigma_{\mathrm{j}}\left(\Delta \alpha_{\mathrm{t}, \mathrm{k}}\right) \text {, is the standard deviation of annual capital returns for each } \\
\text { model } j \text { and each town } k \text {, where } \Delta \alpha_{\mathrm{t}, \mathrm{k}} \text { is the first difference of the estimated } \\
\text { time coefficients between time } \mathrm{t} \text { and } \mathrm{t}-1 \text {. }\end{array}$ & \\
\hline Household density & $\begin{array}{l}\text { Number of family households in town divided by town's land area (in square } \\
\text { miles) in } 2000 \text {. }\end{array}$ & US Census \\
\hline House age & Median age of properties in town $k$. & Calculated \\
\hline Population growth & Population growth for respective period for town $k$. & CT Census \\
\hline PCI & Per capita income in 2000. & US Census \\
\hline New house sales & $\begin{array}{l}\text { Number of sales of houses } 15 \text { years old or less divided to the total number of } \\
\text { sales in town } k \text {. }\end{array}$ & Calculated \\
\hline $\begin{array}{l}\text { Effective property } \\
\text { tax rate }\end{array}$ & Effective property tax rate of town $k$. & $\begin{array}{l}\text { Econ Dept., } \\
\text { U of CT }\end{array}$ \\
\hline $\begin{array}{l}\text { Growth in the } \\
\text { property tax levy }\end{array}$ & Growth in the property tax levy of town $k$. & $\begin{array}{l}\text { Econ Dept., } \\
\text { U of CT }\end{array}$ \\
\hline $\begin{array}{l}\text { Percent owner } \\
\text { occupied }\end{array}$ & Ratio of owner occupied housing to total number of housing units. & US Census \\
\hline
\end{tabular}




\section{Table 2: Summary statistics for the hedonic variables by towns}

The table shows the distribution of town means (Town Mean) and town standard deviations (Town SD) of hedonic variables. The definition of all variables is given in Table 1. The sample includes 162,454 singlefamily residential properties sold between 1994 and 2007 in 53 towns in Connecticut.

\begin{tabular}{|c|c|c|c|c|c|}
\hline & & $1^{\text {st }}$ quartile & Median & Mean & $3^{\text {rd }}$ quartile \\
\hline \multirow{2}{*}{$\ln (\mathrm{PRICE})$} & Town Mean & 12.06 & 12.39 & 12.46 & 12.66 \\
\hline & Town SD & 0.41 & 0.46 & 0.48 & 0.54 \\
\hline \multirow{2}{*}{$\mathrm{LV}_{2}$} & Town Mean & 0.249 & 0.250 & 0.249 & 0.250 \\
\hline & Town SD & 0.433 & 0.433 & 0.432 & 0.433 \\
\hline \multirow{2}{*}{$\mathrm{LV}_{3}$} & Town Mean & 0.250 & 0.250 & 0.251 & 0.251 \\
\hline & Town SD & 0.433 & 0.433 & 0.434 & 0.434 \\
\hline \multirow{2}{*}{$\mathrm{LV}_{4}$} & Town Mean & 0.250 & 0.250 & 0.250 & 0.250 \\
\hline & Town SD & 0.433 & 0.433 & 0.433 & 0.433 \\
\hline \multirow{2}{*}{ AGE } & Town Mean & 31.82 & 38.72 & 39.96 & 47.97 \\
\hline & Town SD & 18.16 & 20.10 & 19.95 & 21.62 \\
\hline \multirow{2}{*}{ FOOTAGE } & Town Mean & 1,525 & 1,734 & 1,853 & 2,096 \\
\hline & Town SD & 567 & 740 & 864 & 903 \\
\hline \multirow{2}{*}{ LOTSF } & Town Mean & 17,234 & 29,033 & 34,860 & 47,171 \\
\hline & Town SD & 19,422 & 29,539 & 30,056 & 38,499 \\
\hline \multirow{2}{*}{ BATH2OR3 } & Town Mean & 0.362 & 0.525 & 0.501 & 0.621 \\
\hline & Town SD & 0.469 & 0.481 & 0.477 & 0.495 \\
\hline \multirow{2}{*}{ BATH3P } & Town Mean & 0.012 & 0.034 & 0.067 & 0.070 \\
\hline & Town SD & 0.106 & 0.180 & 0.201 & 0.255 \\
\hline \multirow{2}{*}{ YEAR } & Town Mean & 2,001 & 2,002 & 2,001 & 2,002 \\
\hline & Town SD & 3.70 & 3.91 & 3.82 & 4.17 \\
\hline \multicolumn{2}{|c|}{ Total no. of observations: } & 162,454 & & & \\
\hline & No. of towns: & 53 & & & \\
\hline
\end{tabular}


Table 3: Summary statistics for the intensity variables by towns

The table shows the distribution of town means (Town Mean) and town standard deviations (Town SD) of intensity variables. The definition of all variables is given in Table 1 . The sample includes 162,454 singlefamily residential properties sold between 1994 and 2007 in 53 towns in Connecticut.

\begin{tabular}{|c|c|c|c|c|c|}
\hline & & $1^{\text {st }}$ quartile & Median & Mean & $3^{\text {rd }}$ quartile \\
\hline \multirow{2}{*}{ LINT } & Town Mean & 0.065 & 0.376 & 0.293 & 0.588 \\
\hline & Town SD & 0.448 & 0.552 & 0.608 & 0.741 \\
\hline \multirow{2}{*}{ LINT_Z } & Town Mean & 0.199 & 0.200 & 0.202 & 0.201 \\
\hline & Town SD & 1.397 & 1.399 & 1.406 & 1.403 \\
\hline \multirow{2}{*}{ LINT25 } & Town Mean & 2.499 & 2.500 & 2.500 & 2.501 \\
\hline & Town SD & 4.331 & 4.331 & 4.331 & 4.332 \\
\hline \multirow{2}{*}{ LINTG75' } & Town Mean & 2.499 & 2.500 & 2.500 & 2.501 \\
\hline & Town SD & 4.330 & 4.331 & 4.331 & 4.332 \\
\hline \multicolumn{2}{|c|}{ Total no. of observations: } & 162,454 & & & \\
\hline & No. of towns: & 53 & & & \\
\hline
\end{tabular}




\section{Table 4: Regression results of Model 1}

We run separate hedonic regressions (equation 4) for each town. This table shows distribution of coefficients across town regressions. Town level results are available upon request. The definition of all variables is provided in Table $1 . \mathrm{N}(+, \mathrm{sig})$ is the number of positive coefficients significant at the $5 \%$ level. $\mathrm{N}(-$, sig) is the number of negative coefficients significant at the 5\% level. Year dummy coefficients are suppressed; available upon request.

\section{Panel A: Distribution of Hedonic Coefficients}

\begin{tabular}{|c|c|c|c|c|c|c|}
\hline & $1^{\text {st }}$ quartile & Median & Mean & $3^{\text {rd }}$ quartile & $\mathrm{N}(+$, sig $)$ & $\mathrm{N}(-$, sig $)$ \\
\hline Constant & 11.14 & 11.46 & 11.42 & 11.71 & 53 & 0 \\
\hline $\mathrm{LV}_{2}$ & -0.033 & 0.043 & 0.069 & 0.151 & 15 & 3 \\
\hline $\mathrm{LV}_{3}$ & 0.035 & 0.159 & 0.150 & 0.258 & 30 & 3 \\
\hline $\mathrm{LV}_{4}$ & 0.071 & 0.248 & 0.253 & 0.376 & 34 & 3 \\
\hline FTG & $2.94 \mathrm{E}-04$ & $3.68 \mathrm{E}-04$ & $3.76 \mathrm{E}-04$ & $4.41 \mathrm{E}-04$ & 51 & 0 \\
\hline $\mathrm{LV}_{2} \times \mathrm{FTG}$ & $-5.49 \mathrm{E}-05$ & $2.25 \mathrm{E}-05$ & $1.56 \mathrm{E}-05$ & $1.01 \mathrm{E}-04$ & 9 & 9 \\
\hline $\mathrm{LV}_{3} \times \mathrm{FTG}$ & $-5.45 \mathrm{E}-05$ & $1.13 \mathrm{E}-05$ & 8.91E-06 & $1.09 \mathrm{E}-04$ & 8 & 8 \\
\hline $\mathrm{LV}_{4} \times \mathrm{FTG}$ & $-1.10 \mathrm{E}-04$ & $-1.89 \mathrm{E}-05$ & $-2.26 \mathrm{E}-06$ & $6.66 \mathrm{E}-05$ & 11 & 13 \\
\hline $\mathrm{FTG}^{2}$ & $-4.21 \mathrm{E}-08$ & $-2.32 \mathrm{E}-08$ & $-3.03 \mathrm{E}-08$ & $-9.98 \mathrm{E}-09$ & 1 & 33 \\
\hline $\mathrm{LV}_{2} \times \mathrm{FTG}^{2}$ & $-2.17 \mathrm{E}-08$ & $-3.87 \mathrm{E}-09$ & $-3.93 \mathrm{E}-09$ & $1.32 \mathrm{E}-08$ & 8 & 10 \\
\hline $\mathrm{LV}_{3} \times \mathrm{FTG}^{2}$ & $-1.91 \mathrm{E}-08$ & $-4.28 \mathrm{E}-09$ & $-2.16 \mathrm{E}-09$ & $1.54 \mathrm{E}-08$ & 7 & 8 \\
\hline $\mathrm{LV}_{4} \times \mathrm{FTG}^{2}$ & $-1.13 \mathrm{E}-08$ & 4.84E-09 & 3.72E-09 & $1.93 \mathrm{E}-08$ & 10 & 9 \\
\hline LOTSF & $2.54 \mathrm{E}-06$ & 3.82E-06 & $5.38 \mathrm{E}-06$ & $6.84 \mathrm{E}-06$ & 50 & 2 \\
\hline LOTSF $^{2}$ & $-3.49 \mathrm{E}-11$ & $-1.45 \mathrm{E}-11$ & $-2.90 \mathrm{E}-11$ & $-6.28 \mathrm{E}-12$ & 2 & 45 \\
\hline AGE & $-8.18 \mathrm{E}-03$ & $-6.49 \mathrm{E}-03$ & $-6.34 \mathrm{E}-03$ & $-4.39 \mathrm{E}-03$ & 1 & 49 \\
\hline $\mathrm{AGE}^{2}$ & $2.49 \mathrm{E}-05$ & $4.31 \mathrm{E}-05$ & $4.50 \mathrm{E}-05$ & $6.47 \mathrm{E}-05$ & 45 & 3 \\
\hline ВАТН3Р & 0.059 & 0.108 & 0.108 & 0.157 & 40 & 0 \\
\hline BATH2OR3 & 0.038 & 0.053 & 0.058 & 0.077 & 52 & 0 \\
\hline $\mathrm{R}^{2}$ & 0.831 & 0.859 & 0.854 & 0.884 & & \\
\hline Adj R2 & 0.829 & 0.857 & 0.852 & 0.883 & & \\
\hline
\end{tabular}


Panel B: Effect of land value dummies $\left(L V_{q}\right)$ by towns evaluated at mean footage* *see equation 9

\begin{tabular}{crrrrrr}
\hline & $1^{\text {st }}$ quartile & Median $^{1}$ & Mean $^{1}$ & $3^{\text {rd }}$ quartile & $\mathrm{N}(+)$ & $\mathrm{N}(-)$ \\
\hline ME_LV 2 & 0.043 & 0.073 & 0.081 & 0.111 & 51 & 2 \\
& & $(0 \%)$ & $(0 \%)$ & & & \\
ME_LV 3 & 0.090 & 0.143 & 0.153 & 0.198 & 53 & 0 \\
& & $(0 \%)$ & $(0 \%)$ & & & \\
& & & & & \\
ME_LV & 0.132 & 0.202 & 0.250 & 0.333 & 53 & \\
& & $(0 \%)$ & $(0 \%)$ & & & \\
\hline
\end{tabular}

\footnotetext{
${ }^{1}$ Parentheses below the Median and Mean values denote the $p$-value of Wilcoxon Signed Rank test statistic for evaluating Median $\left(M E \_L V_{\mathrm{q}}-\mathrm{ME}_{-} L V_{\mathrm{q}-1}\right)>0$ and $t$-statistic for evaluating Mean $\left(\mathrm{ME} \_L V_{\mathrm{q}}-\mathrm{ME}_{-} L V_{\mathrm{q}-}\right.$ 1) $>0$, respectively. See Hypothesis 1 in equation (10).
} 


\section{Table 5: Marginal effects of properties in the lowest quartile of intensity}

The table shows distribution of a) coefficients of intensity variables for Model 2 and b) ME1 and ME2 for Models 2, 3 and 4. Each model is estimated separately for each town. ME1 (ME2) refers to the percentage price difference between a house with low intensity and one with middle (high) intensity, evaluated at median values by town of the concerned variables; see equations (11)-(13). The definition of all variables is provided in Table $1 . \mathrm{N}(+, \mathrm{sig})$ is the number of positive coefficients significant at the $5 \%$ level. $\mathrm{N}(-, \mathrm{sig})$ is the number of negative coefficients significant at the 5\% level. Bolded figures denote the ME for towns where both ME1 and ME2 are positive and significant (i.e. positive OV towns). See Appendix for the distribution of coefficients of intensity variables for Model 3 and Model 4.

\section{Panel A: Model 2 results}

\begin{tabular}{crrrrrr}
\hline & $1^{\text {st }}$ quartile & Median & Mean & $3^{\text {rd }}$ quartile & $\mathrm{N}(+$, sig $)$ & $\mathrm{N}(-$, sig $)$ \\
\hline LINT_Z & -0.0076 & -0.0034 & 0.0019 & 0.0056 & 14 & 21 \\
LINT25, & -0.0054 & -0.0034 & -0.0027 & -0.0004 & 6 & 34 \\
LINTG75, & 0.0006 & 0.0032 & 0.0031 & 0.0051 & 32 & 2 \\
& & & & & & \\
ME1 & -0.119 & -0.045 & -0.008 & 0.033 & 12 & 24 \\
ME2 & -0.140 & -0.066 & -0.038 & 0.016 & 11 & 29 \\
Positive \& significant ME1 & 0.167 & 0.271 & 0.293 & 0.324 & 12 & 0 \\
Positive \& significant ME2 & $\mathbf{0 . 1 8 8}$ & $\mathbf{0 . 2 4 2}$ & $\mathbf{0 . 2 8 8}$ & $\mathbf{0 . 2 8 5}$ & $\mathbf{1 1}$ & $\mathbf{0}$ \\
ME1 for positive OV towns & $\mathbf{0 . 2 0 4}$ & $\mathbf{0 . 2 9 2}$ & $\mathbf{0 . 3 1 9}$ & $\mathbf{0 . 3 4 0}$ & $\mathbf{1 1}$ & $\mathbf{0}$ \\
\hline
\end{tabular}

Panel B: Model 3 results

\begin{tabular}{crrrrrr}
\hline & $1^{\text {st }}$ quartile & Median & Mean & $3^{\text {rd }}$ quartile & N(+,sig) & N(-,sig) \\
\hline ME1 & -0.126 & -0.055 & -0.020 & 0.023 & 10 & 26 \\
ME2 & -0.155 & -0.064 & -0.044 & 0.008 & 10 & 28 \\
Positive \& significant ME1 & $\mathbf{0 . 2 1 3}$ & $\mathbf{0 . 2 5 3}$ & $\mathbf{0 . 3 0 6}$ & $\mathbf{0 . 3 2 8}$ & $\mathbf{1 0}$ & $\mathbf{0}$ \\
Positive \& significant ME2 & $\mathbf{0 . 1 8 4}$ & $\mathbf{0 . 2 1 3}$ & $\mathbf{0 . 2 8 7}$ & $\mathbf{0 . 3 0 5}$ & $\mathbf{1 0}$ & $\mathbf{0}$ \\
\hline
\end{tabular}


Panel C: Model 4 results:

\begin{tabular}{|c|c|c|c|c|c|c|}
\hline & $1^{\text {st }}$ quartile & Median & Mean & $3^{\text {rd }}$ quartile & $\mathrm{N}(+$, sig $)$ & $\mathrm{N}(-$, sig $)$ \\
\hline \multicolumn{7}{|l|}{$\leq 2000$} \\
\hline ME1 & -0.130 & -0.049 & -0.028 & 0.016 & 10 & 26 \\
\hline ME2 & -0.171 & -0.082 & -0.064 & -0.005 & 7 & 26 \\
\hline Positive \& significant ME1 & 0.158 & 0.192 & 0.285 & 0.349 & 10 & 0 \\
\hline Positive \& significant ME2 & 0.138 & 0.144 & 0.316 & 0.405 & 7 & $\mathbf{0}$ \\
\hline ME1 for positive OV towns & 0.188 & 0.276 & 0.344 & 0.385 & 7 & $\mathbf{0}$ \\
\hline \multicolumn{7}{|l|}{$>2000$} \\
\hline ME1 & -0.108 & -0.045 & -0.002 & 0.019 & 11 & 24 \\
\hline ME2 & -0.135 & -0.059 & -0.017 & 0.010 & 13 & 26 \\
\hline Positive \& significant ME1 & 0.248 & 0.371 & 0.339 & 0.387 & 11 & $\mathbf{0}$ \\
\hline Positive \& significant ME2 & 0.178 & 0.321 & 0.304 & 0.382 & 13 & 0 \\
\hline ME2 for positive OV towns & 0.223 & 0.330 & 0.342 & 0.433 & 11 & $\mathbf{0}$ \\
\hline
\end{tabular}




\section{Table 6: Return volatility}

Panel A shows the distribution of volatilities. Panel B shows the correlation between option value and volatility. Volatility is the return volatility of the price index (time dummy coefficients) for each town, as described in the discussion of hypothesis 3. Option value - ME1 (ME2) equals ME1 (ME2) for positive option value towns and zero otherwise. Positive option value towns are those for which ME1>0 and ME2 $>0$ and significant at 5\%. In Panel A (Panel B) option value (OV) equals ME1 (ME2). ME1 is defined in equations 11a,12a and 13a for Models 2, 3 and 4, respectively. ME2 is defined in equations 11b, 12b and $13 \mathrm{~b}$ for Models 2, 3 and 4, respectively. *, **, *** indicates statistical significance at $10 \%, 5 \%$ and $1 \%$ level, respectively.

Panel A: Return Volatility

\begin{tabular}{lccccc}
\hline Model & $1^{\text {st }}$ quartile & Median & Mean & $3^{\text {rd }}$ quartile & $\mathrm{N}$ \\
\hline Model 2 & $5.54 \%$ & $7.30 \%$ & $8.19 \%$ & $9.50 \%$ & 53 \\
Model 3 & $5.60 \%$ & $7.47 \%$ & $8.29 \%$ & $9.85 \%$ & 53 \\
Model 4 $(<=2000)$ & $3.73 \%$ & $5.40 \%$ & $5.56 \%$ & $7.00 \%$ & 50 \\
Model 4 $(>2000)$ & $4.64 \%$ & $6.13 \%$ & $8.42 \%$ & $12.12 \%$ & 52 \\
\hline
\end{tabular}

Panel B: Correlation between Option Value and Volatility

\begin{tabular}{lccc|ccc}
\hline \multicolumn{3}{c}{ Option Value - ME1 } & \multicolumn{3}{c}{ Option value - ME2 } \\
\hline Model & Pearson correlation & P-value & Pearson correlation & P-value & \\
\hline Model 2 & $27.21 \%$ & 0.05 & $* *$ & $25.45 \%$ & 0.07 & $*$ \\
Model 3 & $26.85 \%$ & 0.05 & $* *$ & $24.63 \%$ & 0.08 & $*$ \\
Model 4 $(<=2000)$ & $8.36 \%$ & 0.56 & & $5.25 \%$ & 0.72 & \\
Model 4 $(>2000)$ & $31.99 \%$ & 0.02 & $* *$ & $32.65 \%$ & 0.02 & $* *$ \\
\hline
\end{tabular}


Table 7: Comparison of positive and zero option value towns

This table shows characteristics of positive and zero option value towns. Positive option value towns in Panel A (Panel B and Panel C) are those for which ME1 in Model 3 (Model 4) is positive and significant at 5\%. We assume that option value is zero for the rest of the towns. Variables are defined in Table $1 . *, * *, * * *$ indicates statistical significance at $10 \%, 5 \%$ and $1 \%$ level, respectively.

\section{Panel A: Model 3}

Because of missing data number of observations decreases to 42 for zero option value towns for Drift in house price and Volatility of house prices

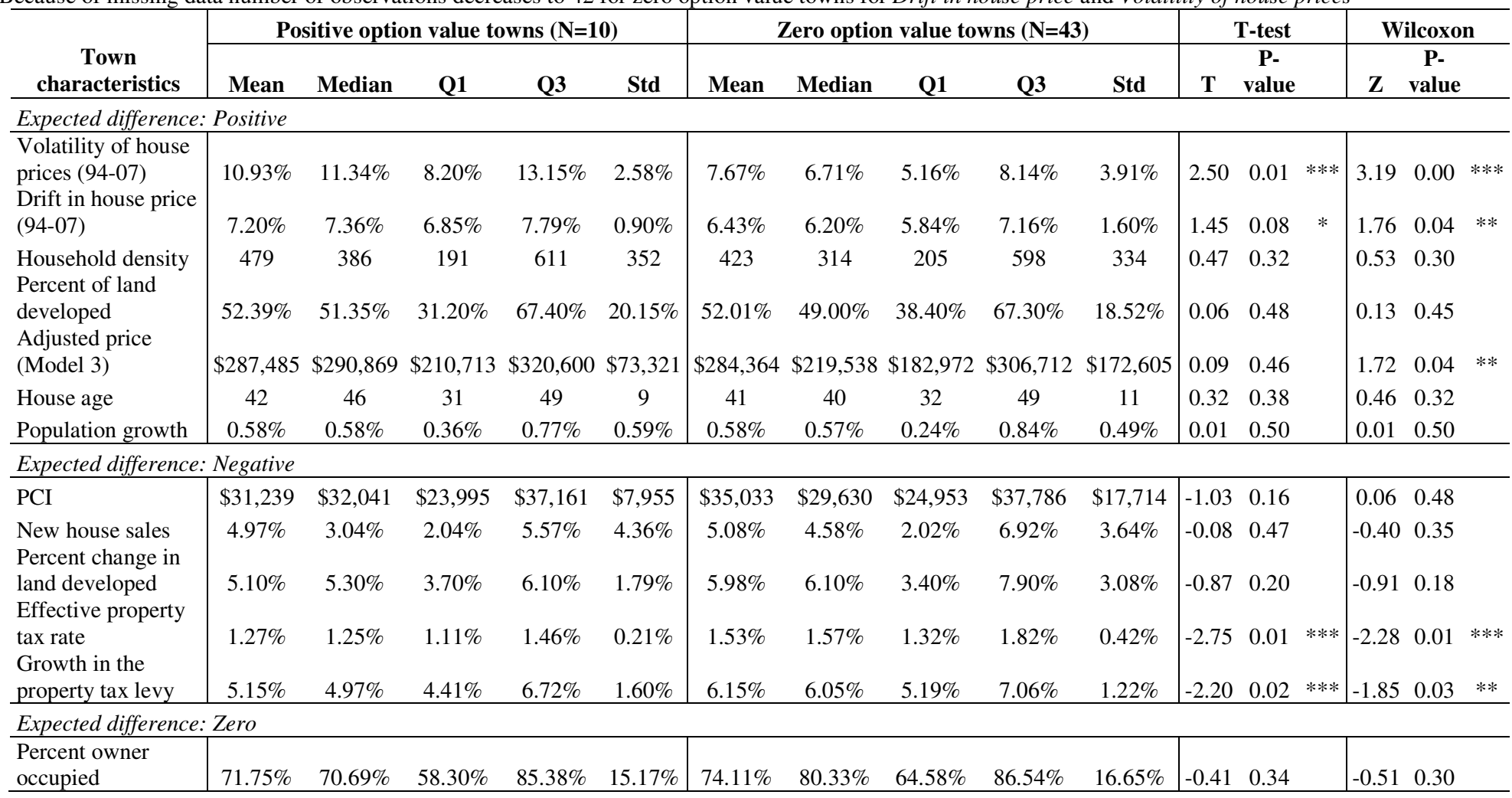


Table 7, continued: Comparison of positive and zero option value towns

Panel B: Model 4 before 2000

Because of missing data number of observations decreases to 43 for zero option value towns for Volatility of house prices.

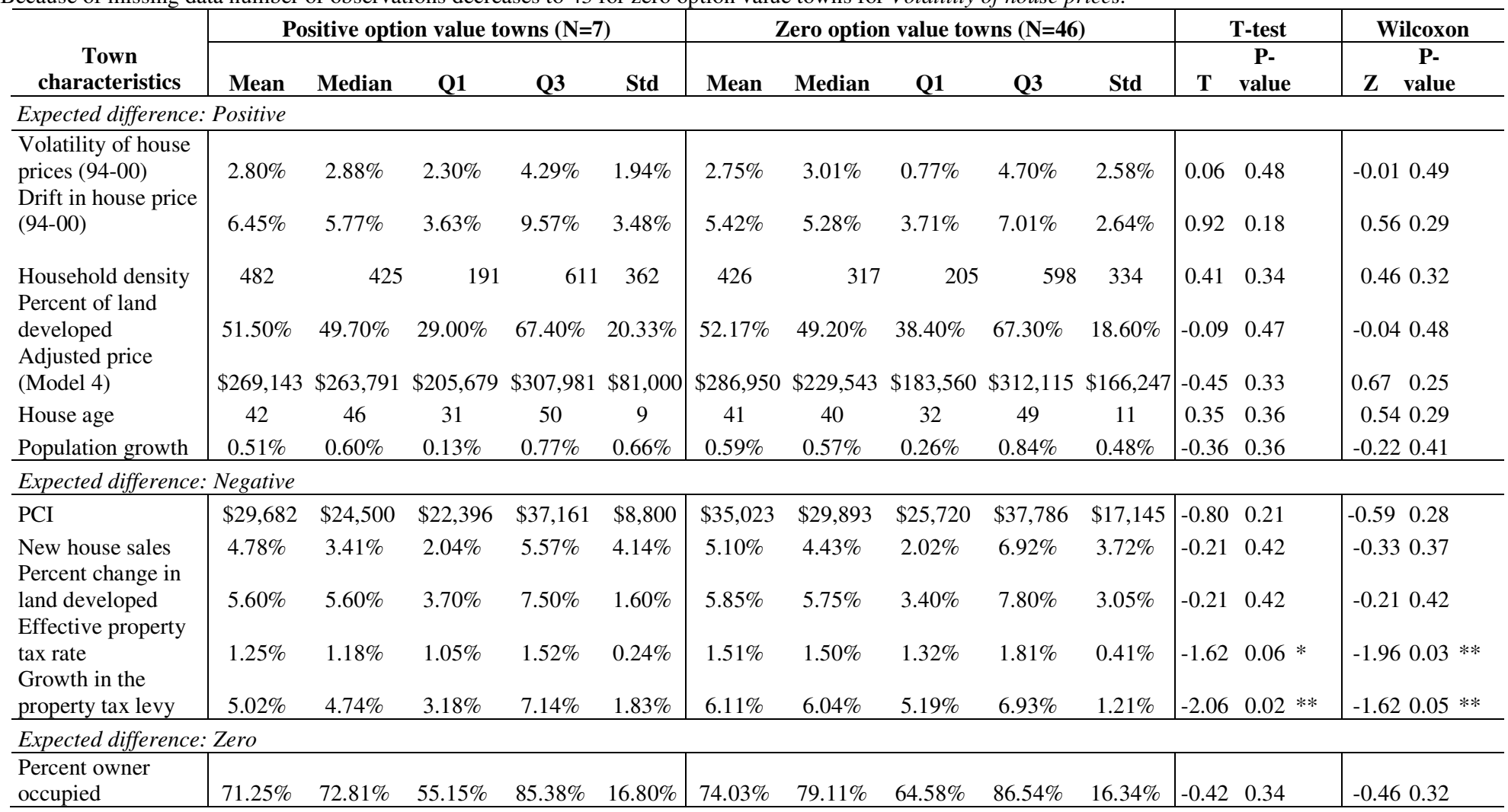


Table 7, continued: Comparison of positive and zero option value towns

Panel C: Model 4 after 2000

Because of missing data number of observations decreases to 41 for zero option value towns for Drift in house price and Volatility of house prices

\begin{tabular}{|c|c|c|c|c|c|c|c|c|c|c|c|c|c|c|}
\hline \multirow[b]{2}{*}{$\begin{array}{c}\text { Town } \\
\text { characteristics }\end{array}$} & \multicolumn{5}{|c|}{ Positive option value towns (N=11) } & \multicolumn{5}{|c|}{ Zero option value towns $(\mathrm{N}=42)$} & \multicolumn{2}{|r|}{ T-test } & \multicolumn{2}{|c|}{ Wilcoxon } \\
\hline & Mean & Median & Q1 & Q3 & Std & Mean & Median & Q1 & Q3 & Std & $\mathbf{T}$ & $\begin{array}{c}\mathrm{P}- \\
\text { value }\end{array}$ & $\mathbf{Z}$ & $\begin{array}{c}\mathrm{P}- \\
\text { value }\end{array}$ \\
\hline \multicolumn{15}{|c|}{ Expected difference: Positive } \\
\hline $\begin{array}{l}\text { Volatility of house } \\
\text { prices (00-07) } \\
\text { Drift in house price }\end{array}$ & $11.70 \%$ & $13.15 \%$ & $7.04 \%$ & $15.50 \%$ & $4.62 \%$ & $7.54 \%$ & $5.62 \%$ & $4.26 \%$ & $8.34 \%$ & $5.96 \%$ & 2.14 & $0.01 * * *$ & 2.80 & $0.00 * * *$ \\
\hline$(00-07)$ & $10.23 \%$ & $10.82 \%$ & $8.57 \%$ & $11.48 \%$ & $1.92 \%$ & $9.47 \%$ & $9.04 \%$ & $8.15 \%$ & $10.68 \%$ & $1.94 \%$ & 1.20 & 0.13 & 1.30 & $0.10 *$ \\
\hline $\begin{array}{l}\text { Household density } \\
\text { Percent of land }\end{array}$ & 456 & 348 & 191 & 611 & 342 & 427 & 317 & 205 & 598 & 337 & 0.25 & 0.20 & 0.20 & 0.42 \\
\hline $\begin{array}{l}\text { developed } \\
\text { Adjusted price }\end{array}$ & $51.46 \%$ & $49.70 \%$ & $31.20 \%$ & $67.40 \%$ & $19.36 \%$ & $52.24 \%$ & $49.20 \%$ & $38.40 \%$ & $67.30 \%$ & $18.68 \%$ & -0.12 & 0.23 & 0.02 & 0.49 \\
\hline (Model 4) & $\$ 281,626$ & $\$ 285,982$ & $\$ 209,747$ & $\$ 330,651$ & $\$ 72,237$ & $\$ 285,377$ & $\$ 218,488$ & $\$ 183,551$ & $\$ 305,564$ & $\$ 173,395$ & 0.11 & 0.23 & 1.55 & $0.06 *$ \\
\hline House age & 41 & 46 & 30 & 49 & 10 & 41 & 40 & 33 & 49 & 11 & -0.04 & 0.24 & 0.09 & 0.46 \\
\hline Population growth & $0.63 \%$ & $0.60 \%$ & $0.36 \%$ & $1.13 \%$ & $0.59 \%$ & $0.56 \%$ & $0.57 \%$ & $0.24 \%$ & $0.79 \%$ & $0.49 \%$ & 0.38 & 0.18 & 0.66 & 0.26 \\
\hline \multicolumn{15}{|c|}{ Expected difference: Negative } \\
\hline PCI & $\$ 31,954$ & $\$ 32,301$ & $\$ 23,995$ & $\$ 39,102$ & $\$ 7,910$ & $\$ 34,936$ & $\$ 29,280$ & $\$ 24,953$ & $\$ 34,987$ & $\$ 17,917$ & -0.82 & $0.10 *$ & 1.12 & 0.13 \\
\hline $\begin{array}{l}\text { New house sales } \\
\text { Percent change in }\end{array}$ & $5.14 \%$ & $3.41 \%$ & $2.04 \%$ & $6.92 \%$ & $4.18 \%$ & $5.03 \%$ & $4.43 \%$ & $2.02 \%$ & $6.89 \%$ & $3.67 \%$ & 0.09 & 0.23 & 0.27 & 0.39 \\
\hline $\begin{array}{l}\text { land developed } \\
\text { Effective property }\end{array}$ & $5.35 \%$ & $5.60 \%$ & $3.70 \%$ & $7.50 \%$ & $1.90 \%$ & $5.93 \%$ & $5.85 \%$ & $3.40 \%$ & $7.80 \%$ & $3.10 \%$ & -0.78 & 0.11 & -0.96 & 0.17 \\
\hline $\begin{array}{l}\text { tax rate } \\
\text { Growth in the }\end{array}$ & $1.28 \%$ & $1.32 \%$ & $1.11 \%$ & $1.46 \%$ & $0.20 \%$ & $1.53 \%$ & $1.59 \%$ & $1.32 \%$ & $1.82 \%$ & $0.42 \%$ & -2.85 & $0.00 * * *$ & -3.18 & $0.00 * * *$ \\
\hline property tax levy & $5.23 \%$ & $5.20 \%$ & $4.41 \%$ & $6.72 \%$ & $1.55 \%$ & $6.15 \%$ & $6.04 \%$ & $5.19 \%$ & $7.06 \%$ & $1.23 \%$ & -2.09 & $0.01 * * *$ & -1.51 & $0.07 *$ \\
\hline \multicolumn{15}{|c|}{ Expected difference: Zero } \\
\hline $\begin{array}{l}\text { Percent owner } \\
\text { occupied }\end{array}$ & $72.08 \%$ & $72.81 \%$ & $58.30 \%$ & $85.38 \%$ & $14.43 \%$ & $74.08 \%$ & $80.34 \%$ & $64.58 \%$ & $86.54 \%$ & $16.85 \%$ & -0.36 & 0.18 & -0.30 & 0.38 \\
\hline
\end{tabular}




\section{Table 8: Likelihood of positive option value (Logit model)}

This table shows estimation of the probability of a town having positive option value using logit model. In specifications Xa dependent variable equals one if ME1 in Model 3 is positive and significant at 5\%, and zero otherwise. In specifications Xb dependent variable equals one if ME1 in Model 4 before 2000 is positive and significant at 5\%, and zero otherwise. In specifications Xc dependent variable equals one if ME1 in Model 4 after 2000 is positive and significant at $5 \%$, and zero otherwise Variables are defined in Table 1. Volatility of house prices, Drift in house price and Adjusted price are calculated for the same model and time period as dependent variable. *,**,** indicates statistical significance at $10 \%, 5 \%$ and $1 \%$ level, respectively.

\begin{tabular}{|c|c|c|c|c|c|c|c|c|c|c|c|c|c|c|c|c|c|}
\hline \multirow[b]{4}{*}{ Variables } & \multicolumn{6}{|c|}{ Model 3} & \multicolumn{5}{|c|}{ Model 4 before 2000} & \multicolumn{6}{|c|}{ Model 4 after 2000} \\
\hline & \multicolumn{3}{|c|}{ Specification 1a } & & \multicolumn{3}{|c|}{ Specification 1b } & & \multicolumn{3}{|c|}{ Specification 1c } & \multicolumn{3}{|c|}{ Specification 2c } \\
\hline & \multicolumn{3}{|c|}{ Wald } & \multirow{2}{*}{\multicolumn{3}{|c|}{ Coeff Wald }} & \multicolumn{3}{|c|}{ Wald } & \multicolumn{2}{|c|}{$\begin{array}{c}\text { Specinication 2D } \\
\text { Wald }\end{array}$} & \multicolumn{3}{|c|}{ Wald } & \multicolumn{3}{|c|}{ Wald } \\
\hline & Coeff & $\chi^{2}$ & & & & & Coeff & $\chi^{2}$ & & Coeff & $\chi^{2}$ & Coeff & $\chi^{2}$ & & Coeff & $\chi^{2}$ & \\
\hline Intercept & -3.145 & 11.45 & $* * *$ & -6.136 & 8.79 & $* * *$ & -2.780 & 13.53 & $* * *$ & -3.003 & $11.54 * * *$ & -2.462 & 12.05 & $* * *$ & -5.908 & 8.11 & $* * *$ \\
\hline Volatility of house prices & 1.622 & 5.16 & $* *$ & 3.083 & $4.40=$ & $* *$ & 0.157 & 0.06 & & 0.246 & 0.13 & 1.506 & 4.58 & $* *$ & 3.058 & 3.92 & $* *$ \\
\hline Drift in house price & 1.190 & 2.08 & & 2.403 & 3.56 & $*$ & -0.190 & 0.09 & & -0.324 & 0.24 & 0.527 & 0.86 & & 2.061 & 4.77 & $* *$ \\
\hline Adjusted price & -4.233 & 6.07 & $* * *$ & 11.675 & $3.03=$ & $*$ & -1.758 & 3.55 & $*$ & 1.362 & 0.16 & -3.534 & 5.53 & $* *$ & 14.337 & 3.69 & $* *$ \\
\hline Effective property tax rate & -3.591 & 6.25 & $* * *$ & -5.027 & 5.42 & $* *$ & -2.521 & 5.77 & $* *$ & -2.556 & $5.24 * *$ & -3.352 & 6.50 & $* * *$ & -6.165 & 5.83 & $* *$ \\
\hline Growth in the property tax levy & -0.815 & 1.59 & & & & & -1.037 & 2.98 & $*$ & -1.155 & $3.01 *$ & -0.548 & 0.82 & & & & \\
\hline Adjusted price squared & & & & -23.802 & 6.30 & $* * *$ & & & & -3.305 & 0.69 & & & & -27.020 & 6.03 & \\
\hline $\mathrm{N}$ & 52 & & & 52 & & & 50 & & & 50 & & 52 & & & 52 & & \\
\hline Likelihood ratio $\chi^{2}$ & 25.05 & & & 35.83 & $* * *$ & & 13.61 & $* *$ & & 14.67 & $* *$ & 15.19 & $* * *$ & & 35.89 & $* * *$ & \\
\hline
\end{tabular}




\section{Table 9: Determinants of option value (Tobit model)}

This table shows tobit model. In specifications Xa dependent variable equals ME1 if ME1 in Model 3 is positive and significant at 5\%, and zero otherwise. In specifications Xb dependent variable equals ME1 if ME1 in Model 4 before 2000 is positive and significant at 5\%, and zero otherwise. In specifications Xc dependent variable equals ME1 if ME1 in Model 4 after 2000 is positive and significant at 5\%, and zero otherwise. Variables are defined in Table 1. Volatility of house prices, Drift in house price and Adjusted price are calculated for the same model and time period as dependent variable. *, **, *** indicates statistical significance at $10 \%, 5 \%$ and $1 \%$ level, respectively.

\begin{tabular}{|c|c|c|c|c|c|c|c|c|c|c|c|c|c|}
\hline & \multicolumn{5}{|c|}{ Model 3} & \multicolumn{4}{|c|}{ Model 4 before 2000} & \multicolumn{4}{|c|}{ Model 4 after 2000} \\
\hline & \multicolumn{3}{|c|}{ Specification 1a } & \multicolumn{2}{|c|}{ Specification 2a } & \multicolumn{2}{|c|}{ Specification 1b } & \multicolumn{2}{|c|}{ Specification $2 \mathbf{b}$} & \multicolumn{2}{|c|}{ Specification 1c } & \multicolumn{2}{|c|}{ Specification 2c } \\
\hline & Coeff & $\mathbf{T}$ & & Coeff & $\mathbf{T}$ & Coeff & $\mathbf{T}$ & Coeff & $\mathbf{T}$ & Coeff & $\mathbf{T}$ & Coeff & $\mathrm{T}$ \\
\hline Intercept & -0.338 & $-3.02 *$ & $* * *$ & -0.408 & $-3.11 * * *$ & -0.527 & $-2.57 * * *$ & -0.555 & $-2.47 * *$ & -0.290 & $-2.73 * * *$ & -0.364 & $-3.08 * * *$ \\
\hline Volatility of house prices & 0.175 & $2.88 *$ & $* * *$ & 0.194 & $3.15 * * *$ & -0.019 & -0.19 & -0.023 & -0.23 & 0.203 & $2.82 * * *$ & 0.182 & $3.01 * * *$ \\
\hline Drift in house price & 0.149 & $2.17 *$ & $* *$ & 0.154 & $2.30 * *$ & 0.000 & 0.00 & -0.003 & -0.03 & 0.051 & 0.86 & 0.108 & $2.07 * *$ \\
\hline Adjusted price & -0.507 & $-4.09 *$ & $* * *$ & 0.528 & 1.23 & -0.438 & $-2.37 * *$ & -0.181 & -0.33 & -0.438 & $-3.34 * * *$ & 0.901 & $1.98 * *$ \\
\hline Effective property tax rate & -0.438 & $-4.03 *$ & $* * *$ & -0.383 & $-4.05 * * *$ & -0.567 & $-2.75 * * *$ & -0.566 & $-2.67 * * *$ & -0.402 & $-3.52 * * *$ & -0.351 & $-4.11 * * *$ \\
\hline Growth in the property tax levy & -0.082 & -1.60 & & & & -0.143 & -1.57 & -0.149 & -1.58 & -0.071 & -1.27 & & \\
\hline Adjusted price squared & & & & -1.359 & $-2.27 * *$ & & & -0.288 & -0.46 & & & -1.689 & $-2.71 * * *$ \\
\hline Sigma & 0.194 & $4.03 *$ & $* * *$ & 0.173 & $4.08 * * *$ & 0.324 & $3.26 * * *$ & 0.328 & $3.23 * * *$ & 0.228 & $4.14 * * *$ & 0.171 & $4.23 * * *$ \\
\hline $\mathrm{N}$ & 52 & & & 52 & & & & 50 & & 52 & & 52 & \\
\hline \# left censored & 42 & & & 42 & & & & 43 & & 41 & & 41 & \\
\hline Log likelihood & -5.57 & ** & & -2.75 & * & -10.1 & $* * *$ & -10.03 & $* * *$ & -8.81 & **** & -3.51 & * \\
\hline
\end{tabular}




\section{Appendix I}

The distribution of coefficients of intensity variables in Models 3 by towns

\begin{tabular}{crrrrrr}
\hline & $1^{\text {st }}$ quartile & Median & Mean & $3^{\text {rd }}$ quartile & $\mathrm{N}(+$, sig $)$ & N(-,sig) \\
\hline LINT_Z & -0.0092 & -0.0037 & 0.0011 & 0.0042 & 13 & 22 \\
LINT25, & 0.0012 & 0.0052 & 0.0061 & 0.0117 & 21 & 3 \\
LINT25*AGE & -0.0006 & -0.0004 & -0.0004 & -0.0001 & 0 & 30 \\
LINT25, *AGE ${ }^{2}$ & $6.69 \mathrm{E}-07$ & $2.71 \mathrm{E}-06$ & $2.94 \mathrm{E}-06$ & $4.59 \mathrm{E}-06$ & 18 & 1 \\
LINTG75, & 0.0045 & 0.0069 & 0.0071 & 0.0110 & 37 & 3 \\
LINTG75,*AGE & -0.0004 & -0.0002 & -0.0002 & $1.95 \mathrm{E}-05$ & 4 & 19 \\
LINTG75,*AGE ${ }^{2}$ & $-1.75 \mathrm{E}-06$ & $8.40 \mathrm{E}-07$ & $7.67 \mathrm{E}-07$ & $3.80 \mathrm{E}-06$ & 15 & 7 \\
\hline
\end{tabular}

The distribution of coefficients of intensity variables in Models 4 by towns

\begin{tabular}{|c|c|c|c|c|c|c|}
\hline & $1^{\text {st }}$ quartile & Median & Mean & $3^{\text {rd }}$ quartile & $\mathrm{N}(+$, sig $)$ & $\mathrm{N}(-$, sig $)$ \\
\hline LINT_Z & -0.0079 & -0.0036 & 0.0015 & 0.0040 & 13 & 20 \\
\hline $\operatorname{LINT}^{2} 5^{\prime} *(\leq 2000)$ & -0.0064 & 0.0026 & 0.0042 & 0.0124 & 14 & 6 \\
\hline LINT25'*AGE* $(\leq 2000)$ & -0.0006 & -0.0003 & -0.0003 & 0.0002 & 4 & 16 \\
\hline LINT $25 * \mathrm{AGE}^{2} *(\leq 2000)$ & $-4.20 \mathrm{E}-06$ & $1.85 \mathrm{E}-06$ & $1.62 \mathrm{E}-06$ & $6.58 \mathrm{E}-06$ & 14 & 6 \\
\hline LINTG75 $*(\leq 2000)$ & 0.0050 & 0.0104 & 0.0104 & 0.0157 & 33 & 0 \\
\hline LINTG75*AGE*( $\leq 2000)$ & -0.0005 & -0.0003 & -0.0003 & $8.55 \mathrm{E}-07$ & 2 & 19 \\
\hline LINTG75 $* \mathrm{AGE}^{2} *(\leq 2000)$ & $-9.52 \mathrm{E}-07$ & 2.17E-06 & $1.86 \mathrm{E}-06$ & $5.59 \mathrm{E}-06$ & 10 & 2 \\
\hline LINT25 $*(>2000)$ & 0.0013 & 0.0059 & 0.0082 & 0.0133 & 20 & 2 \\
\hline LINT25 $*$ AGE* $(>2000)$ & -0.0006 & -0.0003 & -0.0004 & -0.0001 & 1 & 21 \\
\hline LINT25 $* \mathrm{AGE}^{2} *(>2000)$ & 4.18E-07 & $2.67 \mathrm{E}-06$ & $3.16 \mathrm{E}-06$ & $5.29 \mathrm{E}-06$ & 16 & 2 \\
\hline LINTG75 $*(>2000)$ & 0.0013 & 0.0046 & 0.0048 & 0.0088 & 24 & 2 \\
\hline LINTG75*AGE*(> 2000$)$ & -0.0003 & -0.0001 & -0.0001 & 0.0002 & 5 & 13 \\
\hline LINTG75 $* \mathrm{AGE}^{2} *(>2000)$ & $-3.19 \mathrm{E}-06$ & $-3.71 \mathrm{E}-08$ & $1.39 \mathrm{E}-09$ & $3.04 \mathrm{E}-06$ & 12 & 8 \\
\hline
\end{tabular}

